Atmos. Chem. Phys., 18, 15879-15901, 2018

https://doi.org/10.5194/acp-18-15879-2018

(C) Author(s) 2018. This work is distributed under

the Creative Commons Attribution 4.0 License.
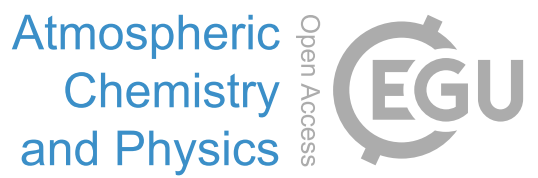

\title{
An automatic observation-based aerosol typing method for EARLINET
}

Nikolaos Papagiannopoulos ${ }^{1,2}$, Lucia Mona ${ }^{1}$, Aldo Amodeo ${ }^{1}$, Giuseppe D’Amico ${ }^{1}$, Pilar Gumà Claramunt ${ }^{1}$, Gelsomina Pappalardo ${ }^{1}$, Lucas Alados-Arboledas ${ }^{3,4}$, Juan Luís Guerrero-Rascado ${ }^{3,4}$, Vassilis Amiridis ${ }^{5}$, Panagiotis Kokkalis $^{5,6}$, Arnoud Apituley ${ }^{7}$, Holger Baars ${ }^{8}$, Anja Schwarz ${ }^{8}$, Ulla Wandinger ${ }^{8}$, Ioannis Binietoglou $^{9}$, Doina Nicolae $^{9}$, Daniele Bortoli ${ }^{10}$, Adolfo Comerón ${ }^{2}$, Alejandro Rodríguez-Gómez ${ }^{2}$, Michaël Sicard ${ }^{2,11}$, Alex Papayannis ${ }^{6}$, and Matthias Wiegner ${ }^{12}$

${ }^{1}$ Consiglio Nazionale delle Ricerche, Istituto di Metodologie per l'Analisi Ambientale (CNR-IMAA),

C.da S. Loja, Tito Scalo (PZ), 85050, Italy

${ }^{2}$ CommSensLab, Dept. of Signal Theory and Communications, Universitat Politècnica de Catalunya, Barcelona, Spain

${ }^{3}$ Andalusian Institute for Earth System Research (IISTA-CEAMA), 18006, Granada, Spain

${ }^{4}$ Department of Applied Physics, University of Granada, 18071, Granada, Spain

${ }^{5}$ IAASARS, National Observatory of Athens, Athens, Greece

${ }^{6}$ Laser Remote Sensing Unit, Physics Dept., National Technical University of Athens, Athens, Greece

${ }^{7}$ Royal Netherlands Meteorological Institute KNMI, De Bilt, the Netherlands

${ }^{8}$ Leibniz Institute for Tropospheric Research (TROPOS), Leipzig, Germany

${ }^{9}$ National Institute of R\&D for Optoelectronics (INOE), Magurele, Romania

${ }^{10}$ Earth Science Institute-(ICT), Évora, Portugal

${ }^{11}$ Ciències i Tecnologies de l'Espai - Centre de Recerca de l'Aeronàutica i de l'Espai/Institut d'Estudis Espacials

de Catalunya (CTE-CRAE/IEEC), Universitat Politècnica de Catalunya, Barcelona, Spain

${ }^{12}$ Ludwig-Maximilians-Universität (LMU), Meteorologisches Institut, Theresienstraße 37, 80333 Munich, Germany

Correspondence: Nikos Papagiannopoulos (nikolaos.papagiannopoulos@imaa.cnr.it)

Received: 27 April 2018 - Discussion started: 30 May 2018

Revised: 18 September 2018 - Accepted: 19 September 2018 - Published: 6 November 2018

\begin{abstract}
We present an automatic aerosol classification method based solely on the European Aerosol Research Lidar Network (EARLINET) intensive optical parameters with the aim of building a network-wide classification tool that could provide near-real-time aerosol typing information. The presented method depends on a supervised learning technique and makes use of the Mahalanobis distance function that relates each unclassified measurement to a predefined aerosol type. As a first step (training phase), a reference dataset is set up consisting of already classified EARLINET data. Using this dataset, we defined 8 aerosol classes: clean continental, polluted continental, dust, mixed dust, polluted dust, mixed marine, smoke, and volcanic ash. The effect of the number of aerosol classes has been explored, as well as the optimal set of intensive parameters to separate different aerosol types. Furthermore, the algorithm is trained with lit-
\end{abstract}

erature particle linear depolarization ratio values. As a second step (testing phase), we apply the method to an already classified EARLINET dataset and analyze the results of the comparison to this classified dataset. The predictive accuracy of the automatic classification varies between $59 \%$ (minimum) and $90 \%$ (maximum) from 8 to 4 aerosol classes, respectively, when evaluated against pre-classified EARLINET lidar. This indicates the potential use of the automatic classification to all network lidar data. Furthermore, the training of the algorithm with particle linear depolarization values found in the literature further improves the accuracy with values for all the aerosol classes around $80 \%$. Additionally, the algorithm has proven to be highly versatile as it adapts to changes in the size of the training dataset and the number of aerosol classes and classifying parameters. Finally, the low computational time and demand for resources make the algorithm 
extremely suitable for the implementation within the single calculus chain (SCC), the EARLINET centralized processing suite.

\section{Introduction}

The European Aerosol Research Lidar Network (EARLINET; Pappalardo et al., 2014) operates Raman lidars at a continental scale. Since the beginning, the network aimed towards a sustainable observing system that has been achieved by developing a quality assurance strategy, and optimizing instruments and data. To this direction and towards future advancement, the network plans continuous measurements and near-real-time data delivery. With this in mind, the single calculus chain (SCC; D'Amico et al., 2015) for automatic lidar analysis has been developed and currently delivers profiles of optical aerosol properties. The EARLINET SCC explores the implementation of new features like profiles of intensive optical properties and determination of aerosol layer geometrical properties. The intensive optical properties are type-dependent and can be used to classify the observed layers into aerosol types. The categorization into different types provides significant help to understand aerosol sources, their effects, and feedback mechanisms to improve the accuracy of satellite retrievals and to quantify assessments of aerosol radiative impacts on climate (Russell et al., 2014) by intercomparing numerical models such as NWP (Numerical Weather Prediction) and CTM (Chemical Transport Model) (Baklanov et al., 2014). Thus, EARLINET, by providing multi-wavelength rangeresolved aerosol properties, has an added value for aerosol typing. In this study we present a flexible automatic method to classify EARLINET data.

Lidar systems are capable of identifying multiple layers in the atmosphere owing to their high vertical resolution (on the order of tens of meters). Thus, lidar-based retrievals can provide a separate classification for each layer and are not confined to columnar classifications as in the case of sun photometers. The lidar technique has proven to be a robust tool to classify aerosols with its capability of polarization-sensitive and multi-wavelength measurements (Liu et al., 2008). Sophisticated lidars, such as the High Spectral Resolution Lidar (HSRL) and the multiwavelength Raman lidars, offer a multitude of intensive parameters that characterize different aerosol types (e.g., Müller et al., 2007a; Burton et al., 2012; Groß et al., 2013). Typically, the particle extinction-to-backscatter ratio (i.e., particle lidar ratio), the particle linear depolarization ratio at one or more wavelengths, and the wavelength dependence of extinction and/or backscatter coefficients (i.e., extinction- or backscatter-related Ångström exponents) are considered.

The increasing amount of available information and particularly the plethora of lidar intensive parameters, can offer a

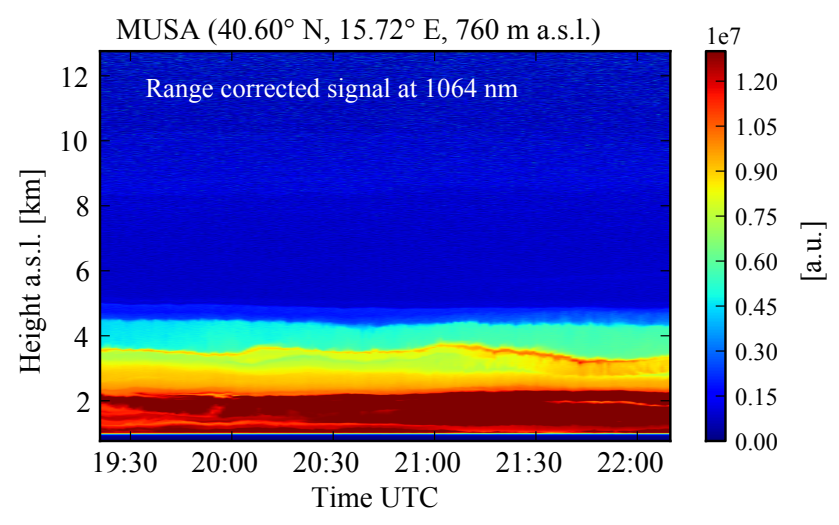

Figure 1. Temporal evolution of the $1064 \mathrm{~nm}$ range-corrected lidar signal obtained with the MUSA system in Potenza on 14 July 2011, 19:20-22:10 UTC.

more accurate aerosol classification as well as insight into the various aerosol types (Burton et al., 2013). Consequently, an objective, multivariate analysis is needed to take advantage of this information. Automatic algorithms are, therefore, employed to classify aerosol into respective types. These procedures make use of various classifiers that are able to quantify the differences between the aerosol classes. In classification analysis, the observations are allocated to a known number of groups, i.e. a supervised learning technique. Whereas in cluster analysis, the groups are not known beforehand and the classifier is tasked with it.

The measured values are evaluated by the classification function to find the group to which the individual most likely belongs. Specifically, distance-based classification techniques (e.g., $k$ nearest neighbor, support vector machine algorithms) are straightforward, i.e. the classification depends on the distance from the target instance to the training instance. The Mahalanobis distance classifier (Mahalanobis, 1936) has a wide range of applications and can be used to categorize data points, each representing an observation, into classes that have predefined characteristics. The distances between the observation and the different classes are calculated, and then the observation is attributed to the class for which the distance is the minimum.

The Mahalanobis-distance-based classification found great applicability in aerosol studies. For instance, the algorithm developed by Burton et al. (2012) makes use of four lidar intensive properties, namely the particle linear depolarization ratio at $532 \mathrm{~nm}$, the particle lidar ratio at $532 \mathrm{~nm}$, the backscatter-related 532 -to-1064 $\mathrm{nm}$ color ratio, and the ratio of particle linear depolarization ratios at 1064 and $532 \mathrm{~nm}$ in order to classify aerosols into 8 types. A slightly different algorithm also including the uncertainties in the input properties was introduced by Russell et al. (2014). Their algorithm was applied to satellite-derived optical and physical data. The reference dataset was obtained from AERONET (Aerosol Robotic Network; Holben et al., 1998) stations, 


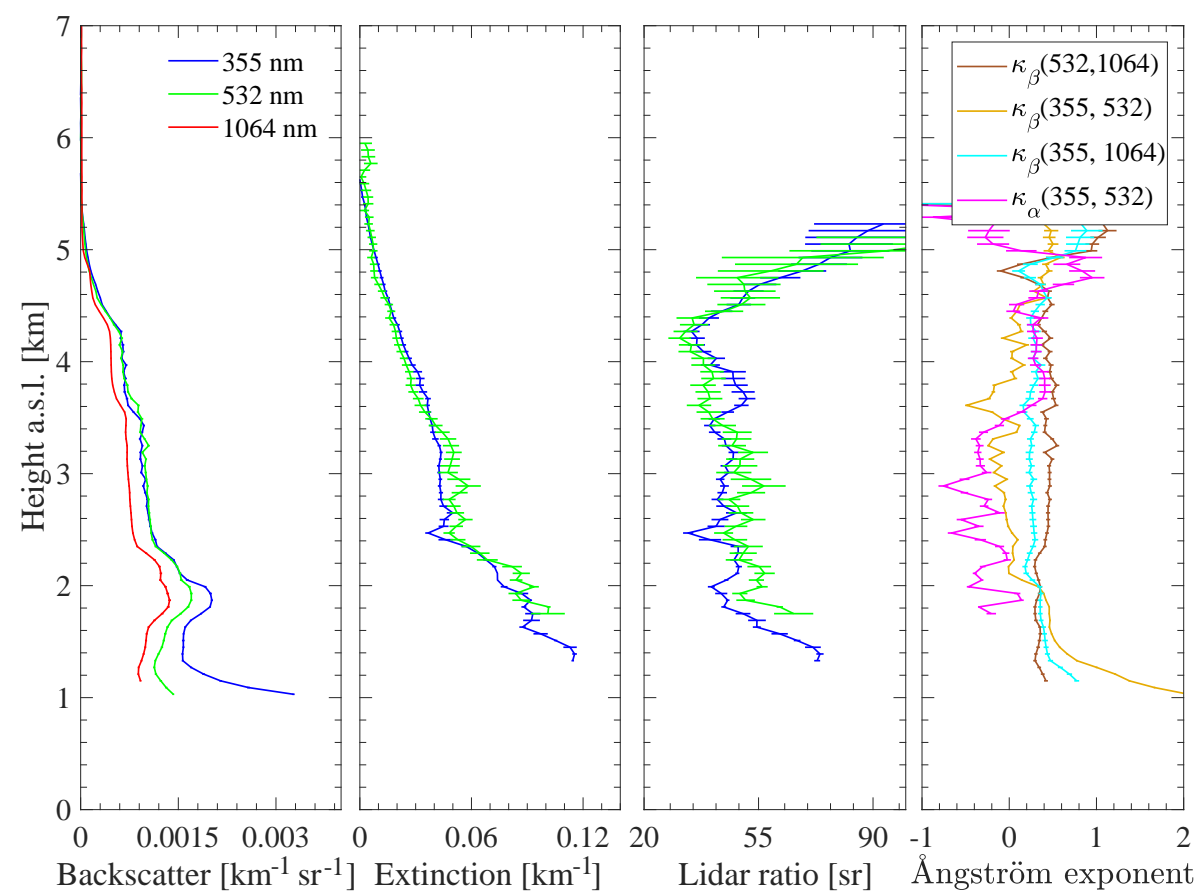

Figure 2. Optical profiles measured in Potenza on 14 July 2011, 19:20-22:10 UTC, with a multi-wavelength Raman lidar. The error bars correspond to the standard deviation.

where a single aerosol type tends to dominate (e.g., Cattrall et al., 2005). The pre-specified classes were then applied to a 5-year record of retrievals from the spaceborne POLDER 3 (Polarization and Directionality of the Earth's Reflectances 3; Tanré et al., 2011) polarimeter on PARASOL (Polarization and Anisotropy of Reflectances for Atmospheric Sciences coupled with Observations from a Lidar; Tanré et al., 2011) spacecraft. Recently, Hamill et al. (2016) used the same classifier to produce an aerosol classification scheme based on long-term AERONET data.

In this work, we present a method analogous to the one proposed by Burton et al. (2012), modified to fit EARLINET's needs and capabilities. The aerosol typing exclusively makes use of EARLINET lidar-derived intensive property data. We use the Mahalanobis distance as a classifier to assign any given multi-dimensional observation to the prespecified aerosol class to which it is most similar. These classes are defined using an EARLINET-based classification scheme. The EARLINET classification scheme is presented in Sect. 2 where we also describe the parameters readily delivered by the network that can be used to classify aerosols. Furthermore, the major aerosol types that comprise the aerosol classes onto which the aerosol classification is based are presented. In Sect. 3 the method that we apply to EARLINET data is explained, and we present the training phase. We set up a scheme for investigating the number of aerosol classes and we perform an analysis to identify the intensive parameters that contribute the most to the classi- fication as well. Section 4 describes the testing phase and provides a discussion of the results of the classification. The paper closes with conclusions of our study and suggestions for further applications and improvements.

\section{Operational network - EARLINET}

EARLINET (https://www.earlinet.org, last access: 10 October 2018) was established in 2000 , providing aerosol profiling data on a continental scale, and is now part of the Aerosols, Clouds, and Trace gases Research InfraStructure (ACTRIS; https://www.actris.eu/, last access: 3 October 2018). In these 18 years of continuous existence, EARLINET has evolved both in the number of contributing stations and in its observing capacity (Pappalardo et al., 2014). Currently, 30 stations are submitting aerosol extinction and/or backscatter coefficient profiles to the EARLINET database, according to EARLINET's measurement schedule (one daytime and two nighttime measurements per week). Therefore, these systematic observations consolidate a 4-D European quantitative and statistically significant aerosol survey. Further measurements are devoted to special events, such as volcanic eruptions, forest fires, and desert dust outbreaks. Moreover, EARLINET provides correlative measurements during CALIPSO (Cloud-Aerosol Lidar and Infrared Pathfinder Satellite Observations) overpasses on each EARLINET station in order to validate satellite products (e.g., Mamouri et al., 2009; Mona et al., 2009). Throughout the paper, we refer to mea- 
surements as a set of aerosol optical profiles reported in the EARLINET database that correspond to the same temporal window, which typically extends for about $1 \mathrm{~h}$. EARLINET data are freely available through the ACTRIS web site (https://www.actris.eu/default.aspx, last access: 15 October 2018) and are published to the CERA database (EARLINET publishing group 2000-2010, 2014a, b, c, d, e; EARLINET publishing group 2000-2015, 2018a, b, c, d, e).

The majority of the EARLINET stations $(67 \%$ of the stations; Pappalardo et al., 2014) operate multi-wavelength Raman lidars that combine a set of elastic and nitrogen inelastic channels, typically consisting of three elastic and two inelastic Raman channels (the so-called $3 \beta+2 \alpha$ configuration). In particular, they provide the aerosol extinction (at 355 and $532 \mathrm{~nm}$ ) and backscatter coefficients (at 355,532 , and $1064 \mathrm{~nm}$ ). This configuration allows for the retrieval of the range-resolved particle lidar ratio at 355 and $532 \mathrm{~nm}\left(S_{\text {aer }}^{\lambda}\right)$. This intensive parameter depends on the shape, size, and chemical composition of the aerosol (Müller et al., 2007a). When lidar ratio is available for more than one wavelength, the corresponding color ratio can also be retrieved $\left(S_{\mathrm{aer}}^{\lambda_{1}} / S_{\mathrm{aer}}^{\lambda_{2}}\right)$. This quantity has shown the ability to characterize the ageing status of smoke particles as well as the spectral dependence of aerosol (Müller et al., 2007a; Alados-Arboledas et al., 2011; Nicolae et al., 2013; Nepomuceno Pereira et al., 2014). The combination of the optical data allows for the retrieval of the size-sensitive backscatter and/or extinction-related Ångström exponent and can be calculated as

$\kappa_{X}\left(\lambda_{1}, \lambda_{2}\right)=\frac{\ln \left[X\left(\lambda_{1}\right) / X\left(\lambda_{2}\right)\right]}{\ln \left(\lambda_{2} / \lambda_{1}\right)}$

with $X$ denoting the backscatter $(\beta)$ or extinction coefficient $(\alpha)$ for a set of wavelengths, $\lambda_{1}$ and $\lambda_{2}$. Moreover, $52 \%$ of EARLINET stations (Pappalardo et al., 2014) are equipped with depolarization channels, thus providing profiles of the particle linear depolarization ratio. It can be calculated according to Biele et al. (2000) and Freudenthaler et al. (2009):

$\delta_{\mathrm{aer}}^{\lambda}=\frac{\left(1+\delta_{\mathrm{m}}\right) \delta_{\mathrm{v}} R-\left(1+\delta_{\mathrm{v}}\right) \delta_{\mathrm{m}}}{\left(1+\delta_{\mathrm{m}}\right) R-\left(1+\delta_{\mathrm{v}}\right)}$

with $R$ being the backscatter ratio, $\delta_{\mathrm{m}}$ the molecular depolarization, and $\delta_{\mathrm{v}}$ the volume depolarization ratio. This parameter provides information on the particle shape, thus enhancing the aerosol typing strength of the network. Under favorable conditions, the aerosol microphysical properties (such as the effective radius), the volume concentration, and the refractive index can also be retrieved through complex numerical algorithms (e.g., Müller et al., 2004; Veselovskii et al., 2010; Bovchaliuk et al., 2016; Chaikovsky et al., 2016).

The data products described above make the EARLINET data an excellent basis to perform aerosol typing at the continental scale. Examples of methodologies to classify aerosol datasets can be found in, e.g., Müller et al. (2007a, b); Groß et al. (2011); Mona et al. (2012a); Navas-Guzmán et al. (2013b), and Baars et al. (2016). For the time being, there are different algorithms under development which combine measurements and aerosol models (Nicolae et al., 2016; Wandinger et al., 2016). Nevertheless, automated observation-based algorithms working at the network level for the identification of layers, their boundaries, and the corresponding aerosol typing are not yet available. The SCC tool for automatic processing of EARLINET lidar signals is, currently, providing primarily profiles of particle extinction and backscatter coefficients, and volume and particle depolarization ratios. The SCC aims at incorporating modules for layer identification, intensive properties retrieval, and aerosol typing. Therefore, this paper could provide a starting point for a harmonized EARLINET classification tool that could also be used by other lidar networks, like the ones involved in GALION (GAW Aerosol Lidar Observation Network), the GAW (Global Aerosol Watch) initiative for the aerosol lidar observation on a global scale, and within aerosol lidar studies in general.

\subsection{EARLINET manual aerosol classification}

The typical procedure for aerosol categorization adopted within the EARLINET community consists of three main steps:

1. layer identification and cloud screening,

2. identification of the geometrical properties (boundaries, center of mass) of the aerosol layer, and

3. the aerosol layer typing by means of investigation of intensive optical properties (Ångström exponents, lidar ratios, and particle linear depolarization ratios), model outputs (backward trajectory analyses), and ancillary instrument data if available (e.g., satellite or sun photometer data).

In what follows, an example of an aerosol type assignment using EARLINET data is presented. Figure 1 shows the temporal evolution of the range-corrected signal at $1064 \mathrm{~nm}$ from a measurement made in Potenza, Italy, on 14 July 2011, 19:20-22:10 UTC with the reference lidar system MUSA (Multiwavelength System for aerosol) of CNR-IMAA (Consiglio Nazionale delle Ricerche - Istituto di Metodologie per l'Analisi Ambientale). High values show a stratified aerosol layer from the ground up to $5 \mathrm{~km}$, whereas low values indicate aerosol-free regions. The lowest altitude range presents the overlap between the laser beam and the receiver field of view and, therefore, it is the blind range of the lidar. MUSA has a full overlap at around $1.15 \mathrm{~km}$ a.s.l. for $1064 \mathrm{~nm}$ (Madonna et al., 2015). The optically thicker layer lies below $2 \mathrm{~km}$, with a distinct layer atop extending up to $3.5 \mathrm{~km}$, and, finally, an optically thinner region from 3.5 to $5 \mathrm{~km}$. 
The retrieved profiles for the same temporal window of particle backscatter and extinction coefficient, lidar ratios, and Ångström exponents are shown in Fig. 2. The particle extinction and backscatter coefficient are given with their full resolution. To calculate the lidar ratio, the backscatter coefficient was smoothed in the same effective vertical resolution using a Savitzky-Golay second-order filter (Iarlori et al., 2015) and only the useful range of signals was kept; the effective resolution of the resulting profiles varied from 120 to $480 \mathrm{~m}$ using the method described in Pappalardo et al. (2004b). The layer $2.0-3.5 \mathrm{~km}$ has a constant behavior with the range for the intensive optical profiles indicating the presence of the same type of particles. The mean values of all optical parameters in the range are calculated: lidar ratios of $48 \pm 4 \mathrm{sr}$ at $355 \mathrm{~nm}$ and $53 \pm 4 \mathrm{sr}$ at $532 \mathrm{~nm}$ and Ångström exponents (i.e., $\kappa_{\beta}(355,1064), \kappa_{\beta}(532,1064), \kappa_{\beta}(355,532)$, and $\left.\kappa_{\alpha}(355,532)\right)$ of -0.3 to 0.4 were found.

For the classification of aerosols with respect to their source regions and age, auxiliary information like results of transport and dispersion models or satellite data are used. For the observed aerosol layer, the Lagrangian dispersion model FLEXPART (FLEXible PARTicle dispersion model; Stohl et al., 2005) was used for a 5-day backward simulation. Figure 3 shows the so-called footprint that indicates the areas of the air parcels traveling below $2 \mathrm{~km}$ before reaching the study area. The model output is given in terms of the decimal logarithm of the integrated residence time in seconds in a grid box. The most probable aerosol source region and the aerosol type were assigned accordingly. The dust-prone area of northern Africa (Morocco and northern Algeria) along with the Mediterranean Sea are most likely the sources of the observed layer and suggest a mixture of dust and marine particles. The combined information of the backward trajectory analysis and the intensive property values indicate the presence of dust particles and they are in accordance with the typical dust values observed over Potenza (Mona et al., 2014).

In the following, the characteristics of the major aerosol types are presented. These aerosol types are used for the automatic classification and correspond to aerosol layers typically encountered over Europe.

\subsection{Aerosol types}

One of the defining characteristics of the aerosol properties is the source; aerosols found in the atmosphere can be, for example, mineral particles from arid areas of the Earth or organic carbon emitted during biomass burning events. Due to the multiple influence of the aerosol origin on the properties, aerosol sources can be used to classify them into different categories. In this section, we provide an overview of the main aerosol types observed over the EARLINET stations followed by the corresponding optical properties. This section also aims to provide important information on the aerosol types that the automatic classification is based upon.

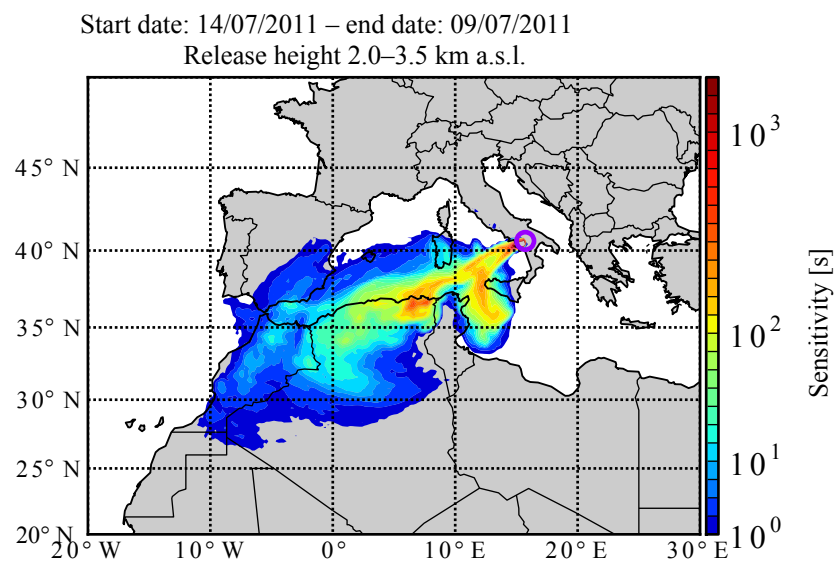

Figure 3. FLEXPART footprint for the air mass traveling below $2 \mathrm{~km}$ height and arriving at Potenza between 2.0 and $3.5 \mathrm{~km}$ at 22:00 UTC on 14 July 2011. The colors are coded with respect to the logarithm of the integrated residence time in a grid box in seconds for a 5-day integration time.

The considered aerosol types almost coincide with the ones used in the CALIPSO classification scheme (Omar et al., 2009), which already provides a satisfactory description of the atmospheric aerosol content. Moreover, adopting similar classification schemes, the direct comparison of the proposed typing against the CALIPSO product is possible.

\subsubsection{Continental}

Man-made activities dictate the aerosol pattern within the atmospheric boundary layer, and affect the observations in the lower troposphere in Europe. Anthropogenic particles show a strong wavelength dependence of their optical properties, i.e., high Ångström exponent values. Moreover, they are typically small and do not significantly depolarize the backscattered light $\left(\delta_{\mathrm{aer}}^{532}=0.04 \pm 0.04\right.$; Heese et al., 2016), and due to the high carbon content, these particles reveal high lidar ratios (Giannakaki et al., 2010). Herein, we refer to this particle type as polluted continental.

Typically, the clean continental aerosol over Europe is a mixture of anthropogenic pollution with particles from natural sources. The clean continental type shows a low depolarizing ability with values lower than 0.07 (Omar et al., 2009); low lidar ratio values, i.e., $20-40 \mathrm{sr}$; and relatively high Ångström exponents, i.e., 1.0-2.5 (Ansmann et al., 2001; Giannakaki et al., 2010). The clean continental, therefore, differentiates from the polluted continental type due to lower lidar ratio values.

\subsubsection{Marine}

Marine particles are produced at the sea surface and dominate the shallow boundary layer over the oceans (e.g., O'Dowd and de Leeuw, 2007). Specifically, the sea-salt par- 
ticles feature a predominant coarse mode; however, they are spherical in humid conditions and weakly absorbing in contrast to the dust particles. Therefore, they yield low particle lidar ratio values, are almost non depolarizing, and exhibit low Ångström exponent values (e.g., Burton et al., 2014; Dawson et al., 2015). This aerosol type is mainly identifiable by the low particle lidar ratio, i.e., $15-25 \mathrm{sr}$ at $532 \mathrm{~nm}$ (Burton et al., 2012). As marine aerosol layers manifest themselves over water bodies, either stations only located at the shorelines and under specific meteorological conditions or shipborne measurements can observe pure maritime particles. Consequently, the observations of pure maritime particles is rare within EARLINET and, generally, when these particles are observed their characteristics are far from pristine (Preißler et al., 2013; Papagiannopoulos et al., 2016a). However, mixtures with important contribution of marine particles can be observed in the Mediterranean basin (Papagiannopoulos et al., 2016a). Thus, we consider pure marine and marine-dominated layers as one single category denoted as mixed marine.

\subsubsection{Mineral dust and dust mixtures}

Mineral dust is produced in arid and semi arid regions of the world, and has a profound contribution to the total natural aerosol loading (Ginoux et al., 2001). The optical properties are considerably different from the other types, thus making them easy to identify. The irregular shape and the large size $(<50 \mu \mathrm{m}$; Mahowald et al., 2014) lead to a significant high depolarization of the backscattered radiation (e.g., $\delta_{\text {aer }}^{532}=0.34 \pm 0.02$ for Saharan dust over Germany; Wiegner et al., 2011), and to medium lidar ratio values (e.g., $S_{\mathrm{aer}}^{532}=55 \pm 10 \mathrm{sr}$; Tesche et al., 2013; Mona et al., 2014). They are spectrally neutral to backscatter and extinction, and thus produce low Ångström exponent values (Wiegner et al., 2011). Therefore, the particle lidar ratio, particle linear depolarization ratio, and the Ångström exponent are excellent physical parameters to characterize mineral dust and to distinguish it from other aerosol types. However, it needs to be taken into account that the dust optical properties depend on the source region and the transport pattern (Valenzuela et al., 2014), which is a source of variability detected in the lidar ratio (e.g., Schuster et al., 2012; Nisantzi et al., 2015). Recently, Mamouri et al. (2013) showed that dust originating from the Arabian desert produced significantly lower lidar ratio values (34-39 sr at $532 \mathrm{~nm}$ ) than respective values (50$60 \mathrm{sr}$ at $532 \mathrm{~nm}$ ) from western Saharan dust particles. An overview on the dust characterization using lidar measurements can be found in Mona et al. (2012b).

Dust can be transported over continental scales. In particular, Saharan dust outbreaks in Europe and across the Atlantic Ocean have been deeply investigated. The European continent is regularly influenced by advected Saharan particles as has been discussed by, e.g., Ansmann et al. (2003); GuerreroRascado et al. (2008, 2009); Papayannis et al. (2008); Müller et al. (2009); Córdoba-Jabonero et al. (2011); Preißler et al. (2011); Valenzuela et al. (2012); Papayannis et al. (2014); Binietoglou et al. (2015); Bravo-Aranda et al. (2015), and Granados-Muñoz et al. (2016a). The study of Papayannis et al. (2008) indicated a large variability in the measured lidar ratio and Ångström exponent values among the different sites, suggesting mixing at different levels. Additionally, the mixture processes also produce large variability in intensive properties as measured at the same site (e.g., Mona et al., 2006, 2014). As a consequence of the complex structure of the observed aerosols over Europe and the effects of transport and mixing on the properties of these particles, we consider the use of three dust groups: pure dust, mixed dust, and polluted dust. The pure dust group refers to particles for which the mixing with other aerosol types is negligible. Mixed dust refers to dust-dominated layers mixed with marine particles. This leads to less depolarizing, and less absorbing particles with respect to pure dust particles. Several studies (Burton et al., 2012; Kim et al., 2013; Rogers et al., 2014; Papagiannopoulos et al., 2016a) have indicated that this mixture is important and suggested its inclusion in the CALIPSO retrieval scheme for improving the accuracy of aerosol backscatter and extinction coefficient profiles. Finally, the polluted dust category consists of dust-dominated mixtures with smoke and/or continental pollution, which produce lower depolarization, higher lidar ratios, and enhanced Ångström exponent values owing to the presence of small, spherical particles (Groß et al., 2011; Burton et al., 2012; Tesche et al., 2013; Bravo-Aranda et al., 2015).

\subsubsection{Smoke}

Biomass burning is a major global source of atmospheric aerosols. Generally, smoke particles are relatively small and spherical that produce low depolarization, high Ångström exponents, and large lidar ratios (Amiridis et al., 2009; Baars et al., 2012; Giannakaki et al., 2016). The optical properties of smoke particles may vary due to the vegetation type of the emitting source, the combustion type (smouldering or flaming fires), and atmospheric conditions (e.g., Balis et al., 2003). Furthermore, the particles are susceptible to changes during their lifetime in the atmosphere (Nicolae et al., 2013). Several EARLINET-based studies have focused on observations and characterization of smoke plumes (e.g., Müller et al., 2005; Papayannis et al., 2008; Ansmann et al., 2009; Tesche et al., 2011; Alados-Arboledas et al., 2011; Nepomuceno Pereira et al., 2014; Ancellet et al., 2016; Ortiz-Amezcua et al., 2017), demonstrating that it is a frequently encountered aerosol type over Europe. In particular, biomass burning aerosol originating from forest fires in Canada and Siberia is regularly observed between May and October (Amiridis et al., 2009; Sicard et al., 2012a; OrtizAmezcua et al., 2017). However, the similarities of the physical characteristics of smoke particles and continental particles result in similar optical properties, making these types 
difficult to distinguish. In this work, biomass burning particles are treated as a single category called smoke.

\subsubsection{Volcanic ash}

Volcanoes are another important source of atmospheric aerosols. Volcanic eruptions eject great amounts of material in the atmosphere (tephra), while the fraction smaller than $2 \mathrm{~mm}$ is labeled as volcanic ash. Most of these aerosols will settle only a few tens of kilometers away from the volcano but smaller particles can travel thousands of kilometers and affect wider areas (Mattis et al., 2010; Sawamura et al., 2012; Sicard et al., 2012b; Navas-Guzmán et al., 2013a; Kokkalis et al., 2013; Pappalardo et al., 2013). The optical properties of volcanic ash aerosols is generally similar to the one of desert dust, as was shown by Ansmann et al. (2010) and Wiegner et al. (2012) for fresh ash with particle linear depolarization ratios reaching 0.37 and lidar ratio at $532 \mathrm{sr}$ of 50-65 sr. Aged volcanic particles as observed by Papayannis et al. (2012) indicate less non-sphericity with depolarization ratio values of $0.1-0.25$ and lidar ratios for $355 \mathrm{~nm}$ within the range 55-67 sr and for $532 \mathrm{~nm} 76-89 \mathrm{sr}$. More details can be found in Mona and Marenco (2016) where the authors give a summary of how the intensive optical properties vary as a function of time. Furthermore, volcanic eruptions inject sulfur dioxide into the atmosphere thus leading to sulfate particles. Pappalardo et al. (2004a) and Wang et al. (2008) reported lidar ratios of 50-60 sr at $355 \mathrm{sr}$ and backscatterrelated Ångström exponent of 2.7 (355 532), signature of sulfate particles originating from Mount Etna, Italy. Moreover, CALIPSO measurements indicated low particle depolarization ratios for sulfate-rich volcanic clouds (Prata et al., 2017). Consequently, the difference in the optical properties make lidar a powerful tool for volcano monitoring. However, in this study sulfate particles and aged volcanic particles are not considered. The aerosol type relevant to the airborne ash refers to fresh ash and is denoted as volcanic ash.

As an additional consideration, the defined aerosol types presented in Sect. 2.2 may not be representative of the entire aerosol load and, apart from the dust mixtures, they do not consider other aerosol mixtures. For example, this aspect can be observed in the definition of the volcanic category where the particles have different characteristics depending on the transport pattern. The particles near the source have optical properties similar to desert dust whereas long-rangetransported volcanic plumes have altered properties due to the sedimentation of the coarser particles. Therefore, it is important to further include a more exhaustive aerosol class analysis.

\section{Automatic aerosol type classification}

\subsection{Methodology}

We developed an automated typing method, based on the work of Burton et al. (2012), but modified it in order to be compatible with the database of EARLINET. Two major steps are identified in the proposed method: the training (Sect. 3.2) and the testing (Sect. 4.1) phase. The first step consists of the following procedures. As described in Sect. 3.2.1, well characterized aerosol layers are manually separated into classes based on their physical characteristics; the set of classes constitutes the reference dataset. This procedure involves the determination of each observed aerosol layer location and the estimation of mean layer intensive optical properties. Based on this analysis, the classifying parameters that provide the required information for a better discrimination of the aerosol type are selected (Sect. 3.2.2). Next, in order to estimate how accurately a predictive model will perform, the reference dataset is split into training and validation datasets, and the application of the classifier is evaluated (Sect. 3.2.3). Section 3.2.4 describes the inference of characteristic depolarization values in the algorithm with the intention to increase the prediction of the model. For the second step, already pre-classified EARLINET data are used to assess the performance of the automatic typing procedure. Figure 4 illustrates the sequence of the proposed methodology starting from the setting of the training dataset, up to the assessment of the learning success during the testing phase.

Distance-based classification methods aim to assign an observation to a particular class based on the distance of the observation from each class center. In general, the Mahalanobis distance between an observation $\mathbf{x}=\left(x_{1}, \ldots, x_{p}\right)^{t}$ and the mean class $\overline{\mathbf{x}}=\left(\bar{x}_{1}, \ldots, \bar{x}_{p}\right)^{t}$ in the $p$-dimensional space $\mathbb{R}^{p}$ is defined as

$D_{\mathrm{M}}(\mathbf{x}, \overline{\mathbf{x}})=\sqrt{(\boldsymbol{x}-\overline{\boldsymbol{x}})^{T} \mathbf{S}^{-1}(\boldsymbol{x}-\overline{\boldsymbol{x}})}$,

where $\mathbf{S}$ is the class covariance matrix. The surfaces identified by the equation $D_{\mathrm{M}}=$ const. are ellipsoids that are centered around the mean $\overline{\mathbf{x}}$. The main characteristic of the multivariate Mahalanobis distance is that it accounts for the variance in each variable and the covariance between variables. By contrast, the Euclidean distance treats all the variables in the same way and the constant distance surfaces from a fixed point are represented by a sphere.

The Mahalanobis distance of an observation from an aerosol class is estimated, and is assigned to the aerosol class for which the distance is minimum. Two screening criteria are applied to the minimum distance following the procedure of Burton et al. (2012). The methodology uses 3 and 4 classifying parameters and the minimum accepted distance for a measurement to be labeled is 4 and 4.3, respectively. Moreover, the normalized probability of the aerosol class needs 


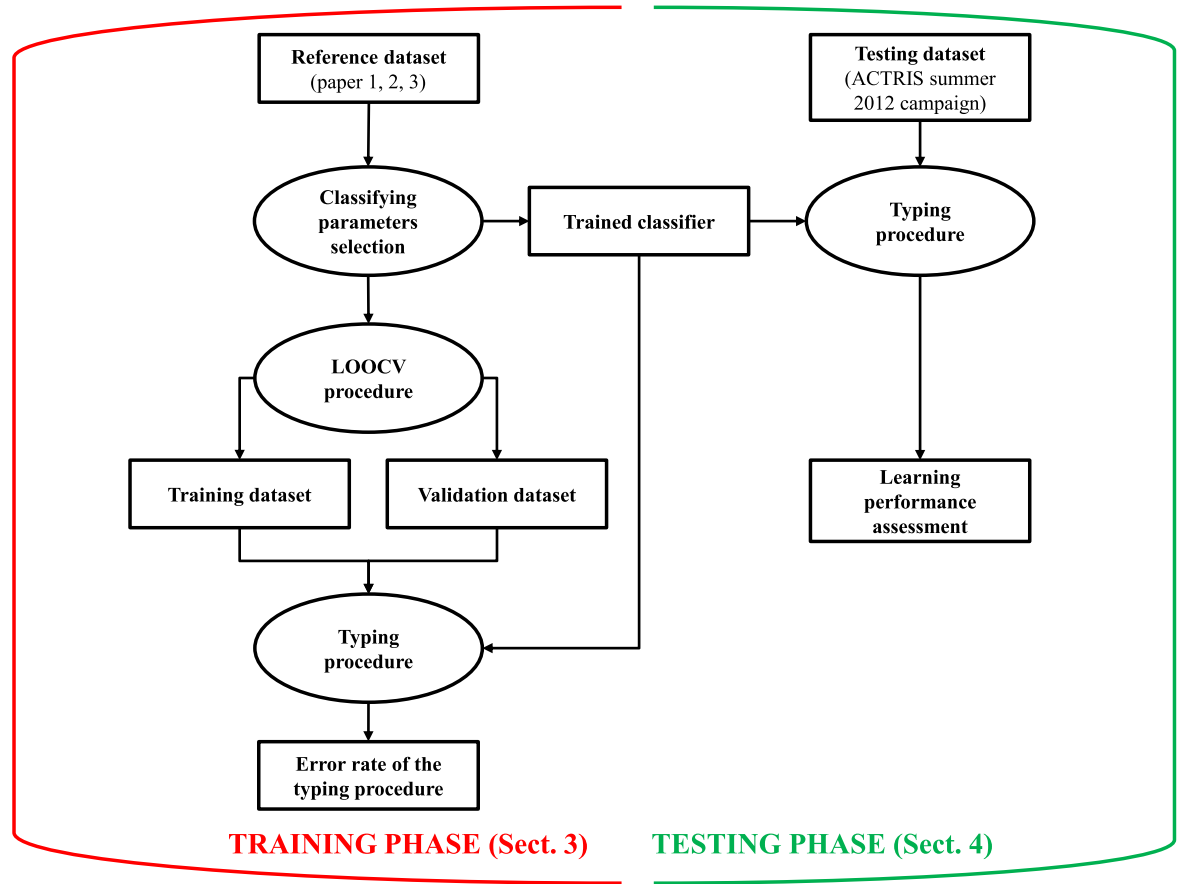

Figure 4. Flowchart of the methodology. First, well characterized aerosol layers are grouped into meaningful classes that represent the reference dataset: paper 1 (Papagiannopoulos et al., 2016a), paper 2 (Pappalardo et al., 2013), and paper 3 (Schwarz, 2016). Second, an analysis is performed to determine the best performing classifying parameters among the available intensive parameters. Third, based on the reference dataset the selected classifier is validated using the leave-one-out cross validation (LOOCV) procedure in order to ensure correct aerosol type separation. Finally, the trained typing algorithm is applied to an independent and manually typed dataset (the testing dataset) for the assessment of the algorithm performance. Note that both phases have been applied with and without the depolarization ratio.

to be higher than $50 \%$. Otherwise, the type assignment is difficult as the measurement can be equidistant from 2 or more aerosol type classes, and possibly indicate the mixing of these aerosol types.

\subsection{Training phase}

\subsubsection{Dataset}

In supervised learning techniques, the reference dataset is crucial to the overall predictive performance of the algorithm. Therefore, it is fundamental to use well-characterized EARLINET profiles. Namely, EARLINET aerosol classified layers from Pappalardo et al. (2013); Papagiannopoulos et al. (2016a), and Schwarz (2016) were used and will be presented below.

EARLINET observations from 2008 to 2010 were analyzed and the aerosol types were determined with respect to the source origin following a similar approach to Sect. 2.1 (Schwarz, 2016) and present the backbone of the reference dataset. Table 1 lists the classified aerosol types of the above study (644 individual aerosol layers) with respect to the aerosol types presented in Sect. 2.2; however, all these aerosol layers cannot be used given the need for the maximum optical properties available (column "only from
Table 1. Number of classified aerosol layers adapted from Schwarz (2016). The mixtures category is comprised of two or more pure aerosol types.

\begin{tabular}{lrr}
\hline Aerosol type & $\begin{array}{r}\text { All } \\
\text { analyzed }\end{array}$ & $\begin{array}{r}\text { Only from } \\
3 \beta+2 \alpha\end{array}$ \\
\hline Clean continental (CC) & 45 & 5 \\
Polluted continental (PC) & 95 & 19 \\
Dust (D) & 41 & 6 \\
Mixed dust (MD) & 56 & 9 \\
Polluted dust (PD) & 14 & 3 \\
Smoke (S) & 24 & 7 \\
Volcanic (V) & 21 & 4 \\
Mixtures & 348 & 35 \\
Total & 644 & 88 \\
\hline
\end{tabular}

$3 \beta+2 \alpha$ "). The mixtures category includes all the mixtures of two or more aerosol species without containing polluted dust and mixed dust categories that are reported individually.

As discussed above, the requirement for $3 \beta+2 \alpha$ lidar configuration pinpoints the low occurrence (see Table 1) of some aerosol types such as the clean continental, polluted dust, and dust. Furthermore, marine aerosol was not reported in the study and the volcanic layers do not reflect the volcanic 
ash characteristics described in Sect. 2.2. Conversely, the latter were volcanic layers found in the stratosphere and thus different from the fresh ash that we consider. In order that the aerosol classes include all the major aerosol components, the aforementioned aerosol types need to be enhanced with other observations. Therefore, we implemented EARLINET network-wide typing results already published in the literature (Pappalardo et al., 2013; Papagiannopoulos et al., 2016a) for a total of 69 layers as the reference dataset. Note that calibrated particle linear depolarization ratio profiles are not available in the selected dataset.

The type-dependent mean properties are reported in Table 2 and coincide with the typical values as of those in Sect. 2.2. However, aerosol classification is based on an interpretative analysis of the retrieved optical properties and the model simulations, and it is a qualitative method of type assignment. Thus, there is an inherent possibility of error in the determination of the true aerosol type. This error, if made, propagates into the automatic algorithm and the predicted aerosol class might deviate from the "truth" aerosol class. Specifically, dust and volcanic types present the same characteristics with Ångström exponents as low as 0, although dust lidar ratios are $58 \pm 12$ and $55 \pm 7 \mathrm{sr}$ for $355 \mathrm{~nm}$ and $532 \mathrm{~nm}$, respectively, and are higher than the volcanic lidar ratios $\left(S_{\mathrm{aer}}^{355}=50 \pm 11\right.$ and $\left.S_{\mathrm{aer}}^{532}=48 \pm 13 \mathrm{sr}\right)$. The Ångström exponents (i.e., $\kappa_{\beta}(355,1064), \kappa_{\beta}(532,1064), \kappa_{\beta}(355,532)$, and $\left.\kappa_{\alpha}(355,532)\right)$ for mixed dust are between 0.4 and 0.7 and lidar ratio values are below $50 \mathrm{sr}$, whereas for polluted dust the Ångström exponents lie within 0.6-1.0 and lidar ratio values for 355 and $532 \mathrm{~nm}$ are $54 \pm 8$ and $64 \pm 9 \mathrm{sr}$, respectively. This behavior reflects the mixing of dust with pollution/smoke that tends to decrease the size of the aerosol mixture and increase its absorbing capacity. Polluted continental and smoke reveal the same size characteristics with mean Ångström exponents from all the available variables around $\sim 1.4$ and $\sim 1.3$, respectively. The smoke mean lidar ratio values present the higher ones among the aerosol types - i.e., $81 \pm 16$ and $78 \pm 11 \mathrm{sr}$ for 355 and $532 \mathrm{~nm}$, respectively - and the polluted continental values succeed with $69 \pm 12$ and $63 \pm$ $13 \mathrm{sr}$ for 355 and $532 \mathrm{~nm}$, respectively. For clean continental, the Ångström exponents (i.e., $\kappa_{\beta}(355,1064), \kappa_{\beta}(532,1064)$, $\kappa_{\beta}(355,532)$, and $\left.\kappa_{\alpha}(355,532)\right)$ are between 1.0 and 1.7 and lidar ratios, for 355 and $532 \mathrm{~nm}$, are $50 \pm 8$ and $41 \pm 6 \mathrm{sr}$. This characteristic separates clean continental from polluted continental as the particles yield lower lidar ratio values. Finally, mixed marine particles are found to be relatively small in size with Ångström exponents (i.e., $\kappa_{\beta}(355,1064)$, $\kappa_{\beta}(532,1064), \kappa_{\beta}(355,532)$, and $\left.\kappa_{\alpha}(355,532)\right)$ in the range $0.8-1.0$ and thus overlap with other aerosol types. The characteristic parameter that defines the mixed marine category is the lidar ratio, the values are found to be the smallest $\left(S_{\text {aer }}^{532}=24 \pm 8 \mathrm{sr}\right)$ among the aerosol types.

In the proposed method, the aerosol layers are classified in terms of the aerosol types described in Sect. 2.2. As a starting point for this study, we use 8 aerosol classes: clean continen- tal (CC), polluted continental (PC), pure dust (D), mixed dust $(\mathrm{MD}=$ dust + marine $)$, polluted dust $(\mathrm{PD}=$ dust + smoke and/or dust + polluted continental), mixed marine (MM), smoke (S), and volcanic $(\mathrm{V})$. However, some of these 8 classes overlap consistently in the feature space. As a consequence, we exploited the combined use of overlapping aerosol types. Therefore, we merged the types that tend to reflect the same aerosol characteristics, and hence we evaluate the corresponding effects on the prediction rate of the algorithm. Two pathways were followed. First, the smoke and the polluted continental categories were grouped into the more generic type of small with high lidar ratio values. Second, all the dust-like aerosol types were merged. The different grouping categories are summarized in Table 3.

\subsubsection{Classifying parameters selection}

Next, we performed a sensitivity analysis to identify which classifying properties provide the adequate information to better predict the correct aerosol class. We used three aerosol intensive properties due to the lack of particle linear depolarization ratio profiles to evaluate the strength of the selected classifier to discriminate among the predefined classes. Two statistical parameters are used: the total and the partial Wilks' lambda $(\Lambda$; Wilks, 1963) that are widely used, e.g., Burton et al. (2012) and Russell et al. (2014). The total $\Lambda$ statistic shows the tendency of the above set of pre-specified classes (or any subset of it) to separate. The partial $\Lambda$ is calculated for each of the intensive properties separately and indicates the discriminatory power of the used intensive property. For both parameters, values range from 0 to 1 . Values near 0 show high discriminatory power while values near 1 show low discriminatory power.

The lowest total $\Lambda$ was found to be 0.033 for the set $\kappa_{\beta}(355,1064), S_{\mathrm{aer}}^{532}$, and $S_{\mathrm{aer}}^{532} / S_{\mathrm{aer}}^{355}$; whereas the partial $\Lambda$ is 0.51 for $S_{\text {aer }}^{532} / S_{\text {aer }}^{355}, 0.17$ for $\kappa_{\beta}$, and 0.30 for $S_{\text {aer }}^{532}$. For this dataset, the low $\Lambda$ value for $\kappa_{\beta}$ indicates that this variable has the most weight in the classification. The decision for the selected parameters stems solely from the lowest arithmetic value of the total $\Lambda$. Therefore, for the other groups of parameters the total $\Lambda$ is equally low, $\sim 0.05$, which indicates that a $2 \beta+2 \alpha$ lidar setup could also be equally used when the algorithm is trained with $\kappa_{\beta}(355,532)$. With reference to the lidar ratio, the $S_{\mathrm{aer}}^{532}$ and $S_{\mathrm{aer}}^{355}$ can be used interchangeably due to the almost equal total $\Lambda$ (i.e., 0.034).

For the rest of the aerosol groups reported in Table 2, the total and partial (for $\kappa_{\beta}$ ) $\Lambda$ are, respectively, 0.036 and 0.18 ( $7^{\mathrm{a}}$ classes), 0.041 and 0.18 ( $7^{\mathrm{b}}$ classes), 0.044 and 0.18 (6 classes), 0.057 and 0.20 (5 classes), and 0.070 and 0.21 (4 classes). The $\Lambda$ shows good discriminatory power for each of the grouping classes, although there is a slight increase in the values as the number of classes is reduced. This behavior can be ascribed to the high variance in the combined aerosol types which makes the classification less selective. 
Table 2. Reference dataset: mean type-dependent intensive properties along with the standard deviation.

\begin{tabular}{lrrrrrrr}
\hline Type & $\kappa_{\beta}(355,1064)$ & $\kappa_{\beta}(532,1064)$ & $\kappa_{\beta}(355,532)$ & $\kappa_{\alpha}(355,532)$ & $S_{\text {aer }}^{355}(\mathrm{sr})$ & $S_{\text {aer }}^{532}(\mathrm{sr})$ & No. of layers \\
\hline CC & $1.0 \pm 0.2$ & $1.0 \pm 0.3$ & $1.3 \pm 0.3$ & $1.7 \pm 0.6$ & $50 \pm 8$ & $41 \pm 6$ & 9 \\
PC & $1.3 \pm 0.3$ & $1.3 \pm 0.2$ & $1.4 \pm 0.6$ & $1.7 \pm 0.5$ & $69 \pm 12$ & $63 \pm 13$ & 16 \\
D & $0.4 \pm 0.1$ & $0.4 \pm 0.1$ & $0.3 \pm 0.2$ & $0.3 \pm 0.4$ & $58 \pm 12$ & $55 \pm 7$ & 9 \\
MD & $0.5 \pm 0.2$ & $0.4 \pm 0.3$ & $0.7 \pm 0.3$ & $0.5 \pm 0.3$ & $42 \pm 4$ & $47 \pm 6$ & 10 \\
PD & $0.9 \pm 0.3$ & $0.8 \pm 0.1$ & $1.0 \pm 0.5$ & $0.6 \pm 0.2$ & $54 \pm 8$ & $64 \pm 9$ & 5 \\
MM & $0.8 \pm 0.1$ & $0.8 \pm 0.2$ & $1.0 \pm 0.3$ & $0.9 \pm 0.3$ & $25 \pm 7$ & $24 \pm 8$ & 8 \\
S & $1.3 \pm 0.1$ & $1.3 \pm 0.1$ & $1.2 \pm 0.3$ & $1.3 \pm 0.3$ & $81 \pm 16$ & $78 \pm 11$ & 7 \\
V & $0.1 \pm 0.1$ & $0.4 \pm 0.3$ & $0.2 \pm 0.3$ & $0.2 \pm 0.3$ & $50 \pm 11$ & $48 \pm 13$ & 5 \\
\hline
\end{tabular}

Table 3. Aerosol types that constitute the classes investigated. CC stands for clean continental, PC stands for polluted continental, D stands for dust, MD stands for mixed dust, PD stands for polluted dust, MM stands for mixed marine, S stands for smoke, and V stands for volcanic particles.

\begin{tabular}{lllllllll}
\hline No. types & \multicolumn{7}{c}{ Groups of aerosol types } \\
\hline 8 & D & V & MD & PD & CC & MM & PC & S \\
$7^{\mathrm{a}}$ & D + V & MD & PD & CC & MM & PC & S & \\
$7^{b}$ & D & V & MD & PD & CC & MM & PC + S & \\
6 & D + V & MD & PD & CC & MM & PC+S & & \\
5 & D +V+MD+PD & CC & MM & PC & S & & \\
4 & D+V+MD+PD & CC & MM & PC + S & & & \\
\hline
\end{tabular}

Figure 5 shows the characteristics of the reference dataset in terms of the $S_{\text {aer }}^{532}$ and $\kappa_{\beta}(355,1064)$ for the 8 and 4 aerosol classes that represent the maximum and minimum aerosol groupings used. The coloring corresponds to the various classes and the crosshairs indicate the standard deviation of each of the aerosol layers. The $90 \%$ confidence ellipses are calculated using the eigenvalues and eigenvectors of the covariance matrix and define the region that contains $90 \%$ of all the points that can be drawn from the underlying normal class distribution. The various aerosol classes tend to populate specific areas of the graph, whereas the overlap of the neighboring classes is significant, although the classes are better pinpointed as long as we merge classes with similar characteristics. However, the latter does not reflect the obtained values of the statistical parameters (total $\Lambda$ increased from 0.033 for 8 classes to 0.070 for 4 classes), and, as explained above, the reference dataset very well delineates the aerosol types and by combining the neighboring types the variance increases.

\subsubsection{Validation of the classifier}

In order to evaluate the predictive accuracy of the automatic method, it is needed to split the initial reference dataset into a training and a validation dataset. Like this, we use the training dataset to calculate the classification functions and then submit each observation in the validation dataset to the classification function obtained from the training dataset. For this study, we make use of the leave-one-out cross valida- tion (LOOCV) procedure, also referred to as holdout procedure or simply cross validation, which is a degenerate case of the $k$ fold cross validation, where $k$ is chosen as the total number of samples (Rencher, 2002). The choice of the procedure, even though computationally expensive, is used when datasets are sparse and trains the algorithm with as many observations as possible. Each measurement is separately removed from the training dataset in order to compute the classification rule, and this rule is used to classify the removed observation. The error rate is estimated as a percentage of all incorrect predictions divided by the total number of the reference dataset, and is equivalent to 1 minus accuracy. Values near 0 show high predictive performance while values near 1 show low predictive performance. For the classification options of the Table 3, the error rate, expectedly, decreases with decreasing number of aerosol classes $(39 \%$ for 8 classes, $36 \%$ for $7^{\mathrm{a}}$ classes, $30 \%$ for $7^{\mathrm{b}}$ classes, $28 \%$ for 6 classes, $19 \%$ for 5 classes, and $10 \%$ for 4 classes). It should be mentioned that the typing in multiple classes and typing accuracy are two conflicting aspects. The choice of 8 aerosol classes appears to be sufficient to describe the major aerosol components, but ostentatious for a $3 \beta+2 \alpha$ lidar configuration. Four classes, on the other hand, provide a coarse aerosol characterization and the prediction accuracy of the algorithm is expected to increase. 

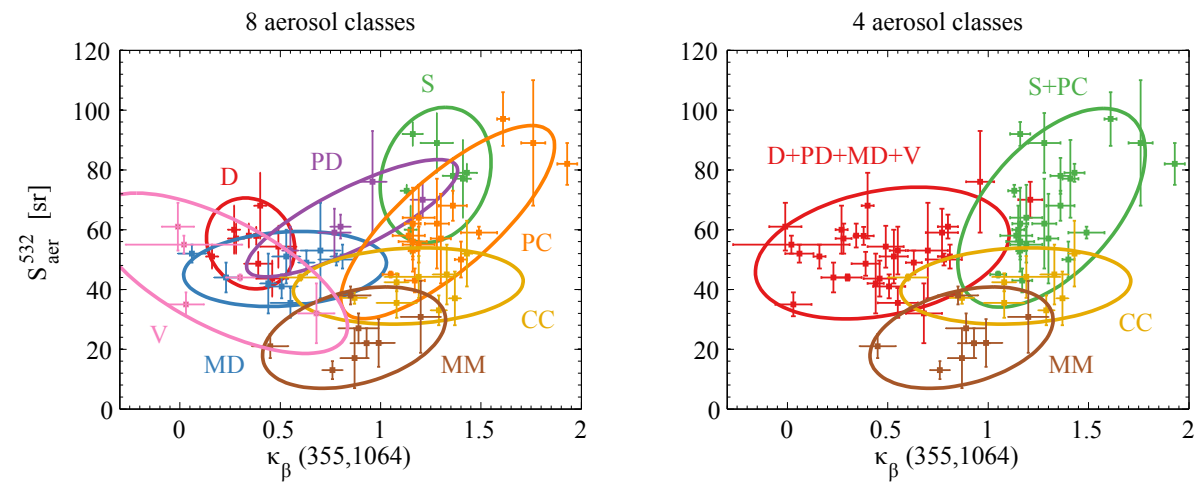

Figure 5. Colored pre-specified classes and $90 \%$ confidence ellipses for 8 and 4 aerosol classes. The error bars correspond to the standard deviation of the selected mean intensive properties. CC stands for clean continental, D stands for dust, MD stands for mixed dust, MM stands for mixed marine, PD stands for polluted dust, PC stands for polluted continental, S stands for smoke, and V stands for volcanic particles.

\subsubsection{Algorithm training including particle depolarization ratio}

Several studies have shown the unique information provided by depolarization measurements (e.g., Liu et al., 2008; Tesche et al., 2013; Burton et al., 2014), thus making this intensive property a robust means to discriminate the various aerosol types. Valuable typing information can also be obtained by the color ratio of the particle depolarization ratios when more depolarization channels exist (Burton et al., 2015). As already stated in Sect. 2, the majority of the stations perform depolarization measurements, and profiles are routinely delivered by SCC. However, the reference dataset does not contain depolarization information because it has been released before the assessment of the quality assurance procedures within EARLINET. Therefore, a method applicable to EARLINET data collected since 2000 is proposed in this work. We investigate the effect of adding depolarization information to the described method as the next releases of EARLINET dataset will contain quality assured particle depolarization profiles and can be used for more accurate aerosol typing. To complement the reference dataset in this context, we used general literature values for particle linear depolarization ratio at $532 \mathrm{~nm}$ (Table 4) in order to train the algorithm. For the clean continental type, the values ingested in the algorithm are retrieved from Burton et al. (2013) and refer to the polluted marine category. The decision for this inconsistency stems from the shortage of clean continental particle depolarization values in the literature; however, the reported values coincide with the type characteristics described in Sect. 2.2 and the values used in the CALIPSO typing scheme (Omar et al., 2009).

In this case, the particle linear depolarization ratio was added to the classifying parameters. Values within the aerosol type range were randomly assigned to each sample and the $\Lambda$ distribution was calculated. Total $\Lambda$ is 0.004 . The value of partial $\Lambda$ for $\kappa_{\beta}(355,1064), S_{\mathrm{aer}}^{532}, S_{\mathrm{aer}}^{532} / S_{\mathrm{aer}}^{355}$, and
Table 4. The mean and standard deviation of the particle depolarization ratio used for the pre-specified classes and the corresponding bibliographic references.

\begin{tabular}{lcl}
\hline Type & $\delta_{\mathrm{aer}}^{532}$ & References \\
\hline Clean continental & $0.04 \pm 0.02$ & Burton et al. (2013) \\
Polluted continental & $0.05 \pm 0.03$ & Burton et al. (2013) \\
Dust & $0.30 \pm 0.01$ & Groß et al. (2011) \\
Mixed dust & $0.15 \pm 0.02$ & Groß et al. (2016) \\
Polluted dust & $0.20 \pm 0.05$ & Burton et al. (2013) \\
Marine & $0.03 \pm 0.01$ & Groß et al. (2013) \\
Smoke & $0.10 \pm 0.04$ & Burton et al. (2013) \\
Volcanic & $0.33 \pm 0.03$ & Pappalardo et al. (2013) \\
\hline
\end{tabular}

$\delta_{\text {aer }}^{532}$ are $0.55,0.34,0.52$, and 0.12 , respectively. The values found for the partial $\Lambda$ confirm the $\delta_{\text {aer }}^{532}$ as the most important classifying parameter for the considered dataset. For the rest of the aerosol groups, the total and partial (for depolarization ratio) $\Lambda$ are, respectively, 0.005 and 0.14 ( $7^{\mathrm{a}}$ classes), 0.005 and 0.12 ( $7^{\mathrm{b}}$ classes), 0.006 and 0.14 (6 classes), 0.040 and 0.68 ( 5 classes), and 0.050 and 0.69 ( 4 classes).

For the sake of completeness, the LOOCV method was also performed and the error rate was calculated. Figure 6 comparatively presents the training of the algorithm when depolarization information is available and when not in terms of the total, partial $\Lambda$, and the error rate of the LOOCV method. The figure highlights the strength of polarizationsensitive observations, while for the 5 and 4 classes (Fig. 6b) the particle linear depolarization ratio becomes less important (in this case the highest weight in the classification corresponds to the lidar ratio at $532 \mathrm{~nm}$ ) due to the fact that only one dust type represents volcanic and other dust mixtures. Figure 7 presents cumulative bar plots with the median (black dots), the 25-75 percentile (box), the 5-95 percentile (whiskers) for all four classifying parameters. The figure highlights the discriminatory power of $\delta_{\mathrm{aer}}^{532}, \kappa_{\beta}(355,1064)$, and $S_{\mathrm{aer}}^{532}$, whereas the $S_{\mathrm{aer}}^{532} / S_{\mathrm{aer}}^{355}$ performs the worst. Further- 

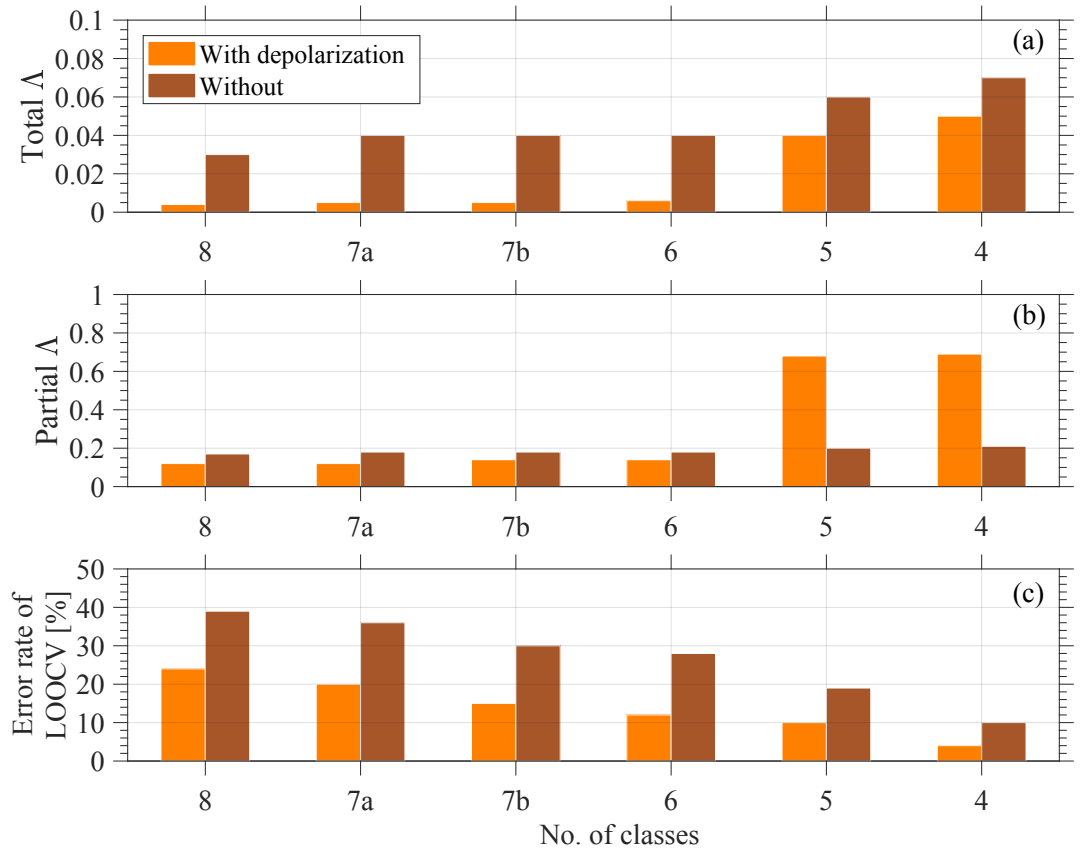

Figure 6. Bar plots showing (a) the total $\Lambda$, (b) the partial $\Lambda$, and (c) error rate of LOOCV when comparing the training of the algorithm with (i.e., $S_{\mathrm{aer}}^{532} / S_{\mathrm{aer}}^{355}, S_{\mathrm{aer}}^{532}$, and $\left.\kappa_{\beta}(355,1064)\right)$ and without $\left(\right.$ i.e., $\delta_{\mathrm{aer}}^{532}, S_{\mathrm{aer}}^{532}$, and $\left.\kappa_{\beta}(355,1064)\right)$ particle linear depolarization values. For the partial $\Lambda$, the brown bars correspond to the backscatter-related Angström exponent and orange one to the particle linear depolarization ratio because they represent the most significant classifying parameter of the classification.

more, the figure depicts the discriminatory power of the classifying parameter among the dust-like aerosol classes; however, the particle depolarization ratio seems to have no power to separate the non-dust classes as discussed above.

\section{Results}

\subsection{Testing phase}

As a next step, an assessment of the predictive performance of the pre-trained algorithm is made by using a testing dataset. For this, EARLINET data collected during the ACTRIS Summer 2012 intensive measurements (Sicard et al., 2015; Granados-Muñoz et al., 2016b) were chosen to test the automatic typing algorithm. The measurements took place in the period of 8 June-17 July 2012 and were dedicated to Saharan dust studies and also featured two field campaigns such as PEGASOS (Pan-European Gas-AeroSOl-climate interaction Study) and CHArMEx (Chemistry-Aerosol Mediterranean Experiment). During that period, 157 measurements were performed, out of which 42 measurements delivered 3 backscatter and 2 extinction coefficient profiles. The description of aerosol type distribution over Europe during the campaign was obtained following the procedure shown in Sect. 2.1 (Papagiannopoulos et al., 2016b). The testing dataset comprises of 47 layers, 21 of which yield depolarization ratio values. Table 5 provides the mean values of the in- tensive parameters for each available category in accordance with Table 2.

\subsection{Application of the methodology to EARLINET data - case studies}

To showcase the steps of the automatic classification, we apply it to two selected cases for the 8 classes and for the classifying parameters: $S_{\mathrm{aer}}^{532} / S_{\mathrm{aer}}^{355}, S_{\mathrm{aer}}^{532}$, and $\kappa_{\beta}(355,1064)$. For the case in Sect. 2.1, the automatic algorithm labeled the aerosol layer as dust, $D_{\mathrm{M}}=1.2$ and the normalized probability $55 \%$. This coincides with our findings and highlights the strength of the classification, albeit this example corresponds to a pure aerosol layer with no level of mixing with other aerosol types.

The second case refers to a more complicated aerosol scene. The Athens EARLINET station (Fig. 8) on 22 May 2014 observed an aerosol layer mostly in the height range between 1.5 and $3 \mathrm{~km}$ (Papayannis et al., 2016). Within this layer the mean value of backscatter-related Ångström exponent $(3551064)$ is $0.9 \pm 0.1$. The lidar ratio presents mean values in the layer $40 \pm 7$ and $39 \pm 6 \mathrm{sr}$ at 355 and $532 \mathrm{~nm}$, respectively. The color ratio of the lidar ratios shows a wavelength-independent layer with values of $1.1 \pm 0.2$. The retrieved error corresponds to the standard deviation of the retrieved quantity calculated within the layer.

In the following, a 6-day FLEXPART backward trajectory indicates the pattern of the origin of air masses. Figure 9 

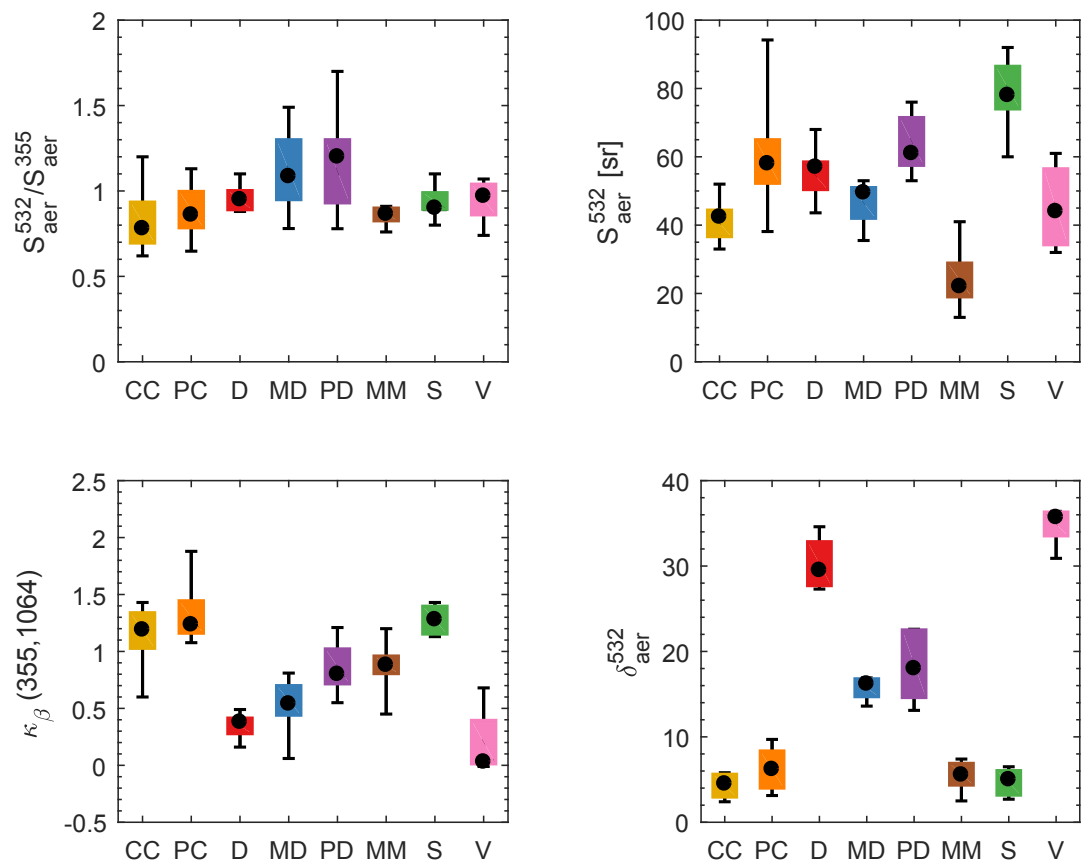

Figure 7. Bar plots show the median (horizontal line), 25-75 percentile (box), and 5-95 percentile (whisker) of the four classifying parameters: $\delta_{\text {aer }}^{532}, \kappa_{\beta}(355,1064), S_{\text {aer }}^{532}$, and $S_{\text {aer }}^{532} / S_{\text {aer }}^{355}$. CC stands for clean continental, D stands for dust, MD stands for mixed dust, MM stands for mixed marine, PD stands for polluted dust, PC stands for polluted continental, S stands for smoke, and V stands for volcanic particles.

Table 5. Testing dataset: mean type-dependent intensive properties along with the standard deviation.

\begin{tabular}{lrrrrrrr}
\hline Type & $\kappa_{\beta}(355,1064)$ & $\kappa_{\beta}(532,1064)$ & $\kappa_{\beta}(355,532)$ & $\kappa_{\alpha}(355,532)$ & $S_{\text {aer }}^{355}(\mathrm{sr})$ & $S_{\text {aer }}^{532}(\mathrm{sr})$ & no. of layers \\
\hline CC & $1.2 \pm 0.4$ & $1.6 \pm 0.4$ & $1.3 \pm 0.2$ & $1.6 \pm 0.4$ & $43 \pm 5$ & $38 \pm 6$ & 12 \\
PC & $1.3 \pm 0.4$ & $1.4 \pm 0.3$ & $1.3 \pm 0.3$ & $1.2 \pm 0.3$ & $52 \pm 6$ & $56 \pm 8$ & 8 \\
D & $0.3 \pm 0.3$ & $0.2 \pm 0.3$ & $0.3 \pm 0.2$ & $0.0 \pm 0.2$ & $54 \pm 11$ & $54 \pm 9$ & 13 \\
MM & $0.8 \pm 0.2$ & $1.2 \pm 0.5$ & $0.9 \pm 0.3$ & $0.9 \pm 0.3$ & $27 \pm 9$ & $24 \pm 8$ & 8 \\
S & $1.6 \pm 0.4$ & $1.6 \pm 0.5$ & $1.5 \pm 0.3$ & $1.6 \pm 0.4$ & $54 \pm 9$ & $61 \pm 6$ & 6 \\
\hline
\end{tabular}

shows the total column sensitivity of the particles found over the station between 1.5 and $3 \mathrm{~km}$, it highlights the motion of the particles in a northeasterly direction towards the Aral Sea and Kazakhstan. This area is an active dust source due to the extreme desiccation of the lake (Ginoux et al., 2012). Therefore, the path of the air masses arriving over Athens suggests a mixture of dust and biomass burning particles, originating from the arid areas of the Aral Sea, as well as the agricultural fires in former Soviet Union countries (Papayannis et al., 2016). The automatic algorithm classified the layer as mixed dust, $D_{\mathrm{M}}=2.5$ and normalized probability $32 \%$, and the second closest class was clean continental, $D_{\mathrm{M}}=3$ and normalized probability $23 \%$. Although the class with the minimum estimated distance agrees with our investigation, the inferred type will not be taken into account. The very low probability indicates that more than one distance is beyond the accepted threshold, therefore the classes are almost equidistant. This demonstrates that the manual typing proce- dure can better type the aerosol layer, but also that adopted fixed thresholds are conservative, i.e., type assignment is not possible for ambiguous scenes.

\subsection{Comparing the automatic classification with manual analyzed data}

The performance of the algorithm with respect to the testing dataset is presented. For each of the grouping classes, as those listed in Table 3, the confusion matrices have been calculated (not shown) and the accuracy of the model is presented alongside the recall $(R)$ and precision $(P)$. The confusion matrix describes the performance of the classifier on a testing dataset for which the typing is already known. Recall of an aerosol group is defined as the number of correctly predicted cases over the number of correctly plus the number of incorrectly predicted cases. Recall can be thought as the model's ability to predict the specific aerosol class. Precision of an aerosol group is defined as the number of correctly 

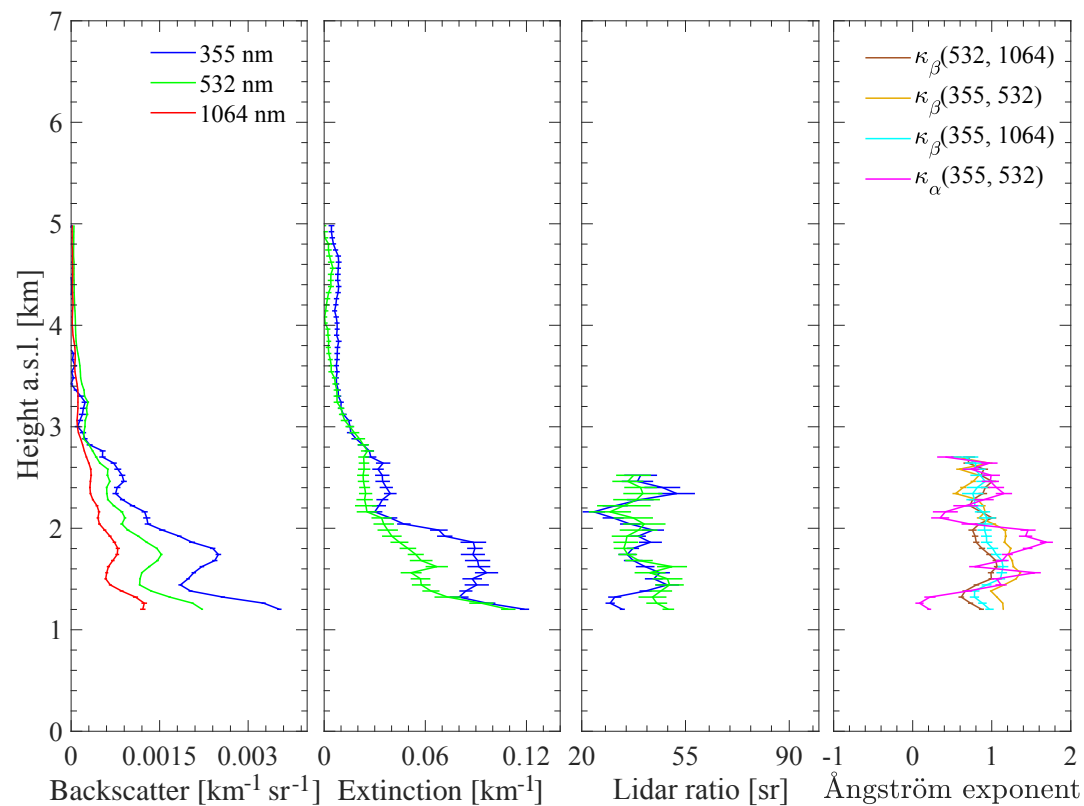

Figure 8. Optical profiles measured at Athens, on 22 May 2014, 20:28-21:28 UTC with a multi-wavelength Raman lidar. The error bars correspond to the standard deviation. The effective resolution of the extinction coefficient profiles varied from 240 to $780 \mathrm{~m}$ using the method described in Pappalardo et al. (2004b).

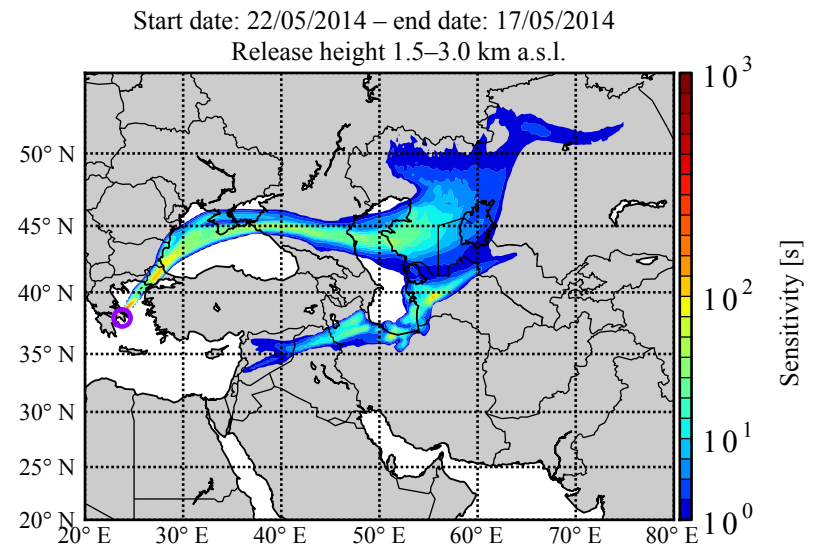

Figure 9. FLEXPART footprint for the air mass traveling below $2 \mathrm{~km}$ height and arriving over Athens between 1.5 and $3.0 \mathrm{~km}$ a.s.l. at 20:28-21:28 UTC on 22 May 2014. The colors represent the logarithm of the integrated residence time in a grid box in seconds for a 6-day integration time.

predicted cases over the number of correctly predicted cases plus the number of incorrectly predicted cases that belong to this aerosol class. In other words, given the prediction of a specific class, what is the probability of being correct?

In Fig. 10, the bar plot comparatively shows the predictive accuracy of the algorithm when compared to manually analyzed data for the different aerosol classes in both the cases in which the depolarization information is available (in orange)

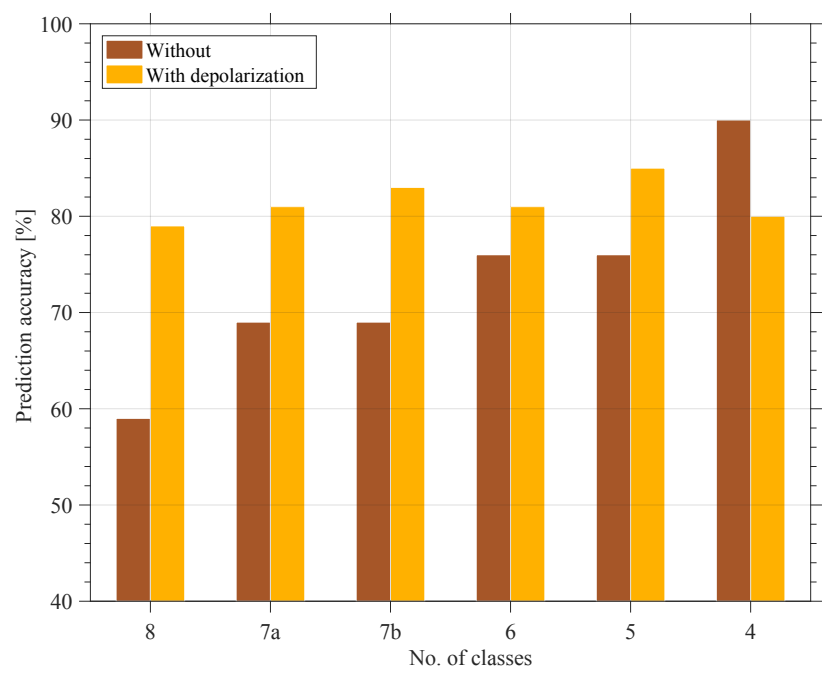

Figure 10. Prediction accuracy for the different aerosol classes with and without depolarization information.

or not (in brown). Without depolarization ratio information, the accuracy of the model increases with decreasing number of classes. The lowest value was obtained for 8 classes $(59 \%)$ and the highest for 4 classes $(90 \%)$. With depolarization ratio information, the accuracy for 8 classes equals to $79 \%$ and exceeds the $80 \%$ for the rest of the aerosol classes. When comparing the accuracy of the model with and without depolarization ratio, it appears to be significantly higher until 6 classes, where the discrepancy diminishes further $(<10 \%)$ 
and becomes smaller for 4 classes. In general, it becomes evident that the particle linear depolarization ratio increases the ability for correctly predicting the aerosol type. Given the high accuracy, a $3 \beta+2 \alpha$ configuration showed that 6 aerosol classes, as well as 5 and 4 , can provide a robust classification. Instead, the training of the classification with depolarization measurements enhances the predictability strength and can provide finer aerosol classification (for 8 classes, accuracy $\sim 70 \%$ ).

Table 6 summarizes the results when using as classifying parameters: $S_{\mathrm{aer}}^{532} / S_{\mathrm{aer}}^{355}, S_{\mathrm{aer}}^{532}$, and $\kappa_{\beta}(355,1064)$, with respect to recall and precision and offers a better insight into the performance of each aerosol type. Next to the number of classes, between parentheses, the number of aerosol layers that passed the screening criteria as those described in Sect. 3.1 is provided. It is, thus, worth noting that the numbers increase when the aerosol types are combined. The mixed marine and clean continental aerosol types yield high recall and precision (values $>80 \%$ ) throughout the different aerosol classes, highlighting the ability of the classifier to correctly label them. The aerosol types that performed worse are the smoke and polluted continental aerosol types due to the similarities in the intensive optical properties. However, when combining them into a single aerosol class (see $7^{\mathrm{b}}, 6$, and 4 classes), precision and recall increase significantly. Given the noticeable signature of dust particles, precision is high, whereas the recall is $30 \%$ and this can be assigned to the lack of depolarization measurements. Similarly, recall increases as soon as volcanic, mixed, and polluted dust are included in the same all-dust category (see $7^{\mathrm{a}}, 6,5$, and 4 classes). Note that mixed dust and polluted dust aerosol types are not reported in the tables due to the fact that they are not present in Table 5 and these parameters cannot be evaluated. The frequency of detection for MD (PD) is $18 \%$ (4\%) for 8 classes, $15 \%$ (3\%) for $7^{\mathrm{b}}$ classes, $17 \%(3 \%)$ for $7^{\mathrm{a}}$ classes, and $15 \%(3 \%)$ when 3 classifying parameters are used. The algorithm predicted MD-only dust cases with $S_{\mathrm{aer}}^{532}$ around $45 \mathrm{sr}$ and $S_{\mathrm{aer}}^{532} / S_{\mathrm{aer}}^{355}$ over 1 . The PD case refers to a PC case with $\kappa_{\beta}(355,1064)$ lower than 1 . The frequency of detection for $\mathrm{MD}$ is $0 \%$ for all classes when depolarization ratio is added. The frequency for PD is $17 \%$ for 8 classes, $13 \%$ for $7^{\mathrm{b}}$ classes, $17 \%$ for $7^{\mathrm{a}}$ classes, and $13 \%$ for 6 classes. The wrongly classified cases have depolarization ratio around $20 \%$.

Table 7 is similar to Table 6 and reports the recall and precision when depolarization information is available. Clean continental aerosol, again, yields high recall and precision for all the different aerosol groups. Polluted continental performed the worst and, expectedly, showed the same behavior as before when compared with smoke in a single type. Alternately, dust is precisely identified for all the aerosol classes. This result indicates that depolarization measurements facilitate the correct dust typing. It is noteworthy that although the findings are promising the test dataset is limited and does not cover all the aerosol classes.

\section{Summary and conclusions}

The characterization of the vertical aerosol distribution is needed for accurate radiative-transfer modeling. Automatic procedures to classify aerosols objectively and within nearreal timescales are employed. An automatic classification procedure based only on EARLINET data was presented. Here, we modified an automatic algorithm to satisfy the network's requirements and needs. A Wilks' lambda analysis was performed on EARLINET data and the three best performing classifying parameters were the lidar ratio at $532 \mathrm{~nm}$, the color ratio of the lidar ratios at 355 and $532 \mathrm{~nm}$, and the backscatter-related 355-to-1064 nm Ångström exponent. Nevertheless, the other intensive parameters using the available wavelengths can be equally used as the analysis showed similar values. Furthermore, the number of aerosol classes has been investigated for a maximum of 8 and minimum 4. Prior to evaluating the performance of the algorithm, the LOOCV procedure was performed on the reference dataset and the error rate decreased monotonically from $39 \%$ to $10 \%$ with decreasing number of aerosol classes. The prediction of the automatic classification showed positive results when compared against already classified EARLINET data. In particular, the positive learning success for $8(59 \%)$, $7\left(69 \%\right.$ for $7^{\mathrm{a}}$ and $7^{\mathrm{b}}$ classes), $6(76 \%), 5(76 \%)$, and 4 $(90 \%)$ classes indicates that the fewer aerosol classes $(6,5$, and 4 classes) provide a confident but, nonetheless, coarser classification. To be more precise, the high accuracy (76\%) coupled with the low error rate of the cross validation $(28 \%)$ for 6 classes offers a good starting point for a classification with a $3 \beta+2 \alpha$ lidar configuration.

Besides, the training of the algorithm with literature depolarization ratio values decreased the error rate of the LOOCV from $24 \%$ (8 classes) to $4 \%$ (4 classes). Furthermore, the predictive accuracy increased and remained for all the aerosol classes around $80 \%$ (for 8 classes: $79 \%$, for $7^{\mathrm{a}}: 81 \%$, for $7^{\mathrm{b}}: 83 \%$, for $6: 81 \%$, for $5: 85 \%$, and for 4 : $80 \%)$. Therefore, this finding suggests that the algorithm in this case can be used for finer aerosol classification and also delineates the discriminatory power of depolarization ratio. Specifically, 7 aerosol classes (either D+V, MD, PD, CC, MM, PC, S or D, V, MD, PD, CC, MM, PC+S) seem to be adequate to provide reasonable typing results. However, the obtained results refer to a small testing dataset that consists of pure aerosol types and underestimates the aerosol mixtures of the classification.

The presented automatic algorithm is only based on EARLINET data and is set to accommodate EARLINET measurements covering as much of its measurement record as possible. Specifically, Raman lidar systems with $3 \beta+2 \alpha$ and $2 \beta+2 \alpha$ configurations with and without particle depolarization ratio can be used for the aerosol classification. The manageability of the algorithm regarding the reference dataset, the number of the aerosol classes, and the classifying parameters make the method easily adaptable and handled by indi- 
Table 6. Recall $(R)$, and precision $(P)$ estimated from the classification matrices for $8,7^{\mathrm{a}}, 7^{\mathrm{b}}, 6,5$, and 4 classes. The values between parentheses correspond to the number of layers passed the screening criteria.

\begin{tabular}{|c|c|c|c|c|c|c|c|c|}
\hline Types & $R(\%)$ & $P(\%)$ & Types & $R(\%)$ & $P(\%)$ & Types & $R(\%)$ & $P(\%)$ \\
\hline \multicolumn{3}{|c|}{8 classes (29/47) } & \multicolumn{3}{|c|}{$7^{\mathrm{a}}$ classes $(29 / 47)$} & \multicolumn{3}{|c|}{$7^{\mathrm{b}}$ classes $(34 / 47)$} \\
\hline $\mathrm{CC}$ & 100 & 82 & $\mathrm{CC}$ & 100 & 89 & $\mathrm{CC}$ & 100 & 90 \\
\hline D & 30 & 100 & $\mathrm{D}+\mathrm{V}$ & 55 & 100 & $\mathrm{D}$ & 27 & 100 \\
\hline MM & 100 & 100 & MM & 100 & 100 & MM & 100 & 100 \\
\hline $\mathrm{PC}$ & 25 & 33 & $\mathrm{PC}$ & 50 & 50 & $\mathrm{PC}+\mathrm{S}$ & 78 & 100 \\
\hline$S$ & 0 & - & $\mathrm{S}$ & 0 & - & & & \\
\hline \multicolumn{3}{|c|}{6 classes $(33 / 47)$} & \multicolumn{3}{|c|}{5 classes $(35 / 47)$} & \multicolumn{3}{|c|}{4 classes $(39 / 47)$} \\
\hline $\mathrm{CC}$ & 100 & 80 & $\mathrm{CC}$ & 100 & 82 & $\mathrm{CC}$ & 100 & 85 \\
\hline $\mathrm{D}+\mathrm{V}$ & 58 & 100 & $\mathrm{D}+\mathrm{V}+\mathrm{PD}+\mathrm{MD}$ & 100 & 87 & $\mathrm{D}+\mathrm{V}+\mathrm{PD}+\mathrm{MD}$ & 100 & 87 \\
\hline MM & 100 & 100 & MM & 100 & 100 & MM & 100 & 100 \\
\hline \multirow[t]{2}{*}{$\mathrm{PC}+\mathrm{S}$} & 63 & 100 & PC & 20 & 33 & $\mathrm{PC}+\mathrm{S}$ & 56 & 100 \\
\hline & & & S & 0 & - & & & \\
\hline
\end{tabular}

Table 7. Recall $(R)$ and precision $(P)$ estimated from the classification matrices for $8,7^{\mathrm{a}}, 7^{\mathrm{b}}, 6,5$, and 4 classes when particle linear depolarization ratio measurements are available. The values between parentheses correspond to the number of layers passed the screening criteria.

\begin{tabular}{|c|c|c|c|c|c|c|c|c|}
\hline Types & $R(\%)$ & $P(\%)$ & Types & $R(\%)$ & $P(\%)$ & Types & $R(\%)$ & $P(\%)$ \\
\hline \multicolumn{3}{|c|}{8 classes $(14 / 21)$} & \multicolumn{3}{|c|}{$7^{\mathrm{a}}$ classes $(13 / 21)$} & \multicolumn{3}{|c|}{$7^{\mathrm{b}}$ classes $(16 / 21)$} \\
\hline $\mathrm{CC}$ & 75 & 100 & $\mathrm{CC}$ & 100 & 100 & $\mathrm{CC}$ & 75 & 100 \\
\hline D & 88 & 100 & $\mathrm{D}+\mathrm{V}$ & 88 & 100 & $\mathrm{D}$ & 88 & 100 \\
\hline MM & - & - & MM & - & - & MM & - & - \\
\hline PC & 50 & 50 & $\mathrm{PC}$ & 100 & 75 & $\mathrm{PC}+\mathrm{S}$ & 75 & 75 \\
\hline $\mathrm{S}$ & - & - & $\mathrm{S}$ & 0 & - & & & \\
\hline \multicolumn{3}{|c|}{6 classes $(16 / 21)$} & \multicolumn{3}{|c|}{5 classes $(13 / 21)$} & \multicolumn{3}{|c|}{4 classes $(15 / 21)$} \\
\hline $\mathrm{CC}$ & 75 & 100 & $\mathrm{CC}$ & 100 & 100 & $\mathrm{CC}$ & 75 & 100 \\
\hline $\mathrm{D}+\mathrm{V}$ & 88 & 100 & $\mathrm{D}+\mathrm{V}+\mathrm{PD}+\mathrm{MD}$ & 100 & 100 & $\mathrm{D}+\mathrm{V}+\mathrm{PD}+\mathrm{MD}$ & 100 & 80 \\
\hline MM & - & - & MM & - & - & MM & - & - \\
\hline $\mathrm{PC}+\mathrm{S}$ & 75 & 75 & $\mathrm{PC}$ & 0 & - & $\mathrm{PC}+\mathrm{S}$ & 33 & 50 \\
\hline & & & $\mathrm{S}$ & - & - & & & \\
\hline
\end{tabular}

vidual users. The training dataset can be easily enlarged with high-quality typing data coming from a multitude of EARLINET stations and a longer time record. Moreover, new classifying parameters, such as particle linear depolarization ratio at more wavelengths and aerosol extinction coefficient in the infrared, can be easily added as the observing capacity increases.

The use of the method network-wide will homogenize and standardize the aerosol typing towards a new EARLINET product. The implementation of the method into the SCC will create a complete automatic lidar analysis, i.e. from the retrieval of optical properties to aerosol classification. Furthermore, an intercomparison of the developed method against methods which also make use of aerosol optical property modeling could improve from one side the optimization of aerosol property models and from the other side the tuning of aerosol types and reference dataset. This method, even if developed on the basis of EARLINET and its variable instrumental capability, can be applied to all of the aerosol lidar systems as those that are part of GALION as well as to future lidar-based satellite missions (e.g., the Earth Cloud, Aerosol and Radiation Explorer, EarthCARE, satellite mission). In future, a combination of the few sophisticated EARLINET-type lidars and extended networks of automated single-wavelength backscatter lidars (such as ceilometers; Wiegner et al., 2014) might be beneficial with aerosol typing provided at "anchor stations", and the spatial extent of the layers can be provided by the continuous observations of the ceilometers. This will also offer a unique dataset for evaluation of models. 
Data availability. The data used in this paper are freely available from the EARLINET (https://www.earlinet.org/index.php?id= earlinet_homepage, last access: 18 October 2018) and ACTRIS (http://www.actris.eu/, last access: 15 October 2018) web sites. A part of them is published to the CERA database (EARLINET publishing group 2000-2010, 2014a, b, c, d) and accessible using the CERA data portal (https://cera-www.dkrz.de/WDCC/ui/ cerasearch/, last access: 19 October 2018). The full dataset up to the end of 2015 is currently in press on the CERA database (EARLINET publishing group 2000-2015, 2018a, b, c, d,, e).

Author contributions. NP conducted the research process and developed the typing algorithm. NP developed the code with support from PGC. NP and LM conducted the statistical analysis and performed the comparison with already pretyped EARLINET data. AA, GD, IB, LM, and VA supervised the project. All authors contributed to the EARLINET data curation and preprocessing. Furthermore, they contributed to the analysis of the results and to the writing of the manuscript.

Competing interests. The authors declare that they have no conflict of interest.

Special issue statement. This article is part of the special issue "EARLINET aerosol profiling: contributions to atmospheric and climate research". It is not associated with a conference.

Acknowledgements. The financial support for EARLINET in the ACTRIS Research Infrastructure Project by the European Union's Horizon 2020 research and innovation program under grant agreement no. 654169 in the Seventh Framework Programme (FP7/2007-2013) is gratefully acknowledged. The research leading to these results has received funding from the European Union's Horizon 2020 research and innovation program under grant agreement no. 602014 (project ECARS - East European Centre for Atmospheric Remote Sensing) and from the European Union's Horizon 2020 research program for societal challenges - smart, green and integrated transport under grant agreement no. 723986 (project EUNADICS-AV - European Natural Disaster Coordination and Information System for Aviation). Daniele Bortoli acknowledges the European Union through the European Regional Development Fund, included in the COMPETE 2020 (Operational Program Competitiveness and Internationalization) through the ICT project (UID/GEO/04683/2013) with reference POCI 01-0145-FEDER 007690. Panagiotis Kokkalis acknowledges funding of the Greek State Scholarship Foundation: IKY. Part of this project is implemented within the framework of the Action "Reinforcement of Postdoctoral Researchers" of the Operational Program "Human Resource Development, Education and Lifelong Learning", and is co-financed by the European Social Fund (ESF) and the Greek government (NSRF, 2014-2020).

Edited by: Matthias Tesche

Reviewed by: Sharon Burton and one anonymous referee

\section{References}

Alados-Arboledas, L., Müller, D., Guerrero-Rascado, J. L., NavasGuzmán, F., Pérez-Ramírez, D., and Olmo, F. J.: Optical and microphysical properties of fresh biomass burning aerosol retrieved by Raman lidar, and star- and sun-photometry, Geophys. Res. Lett., 38, L01807, https://doi.org/10.1029/2010GL045999, 2011.

Amiridis, V., Balis, D. S., Giannakaki, E., Stohl, A., Kazadzis, S., Koukouli, M. E., and Zanis, P.: Optical characteristics of biomass burning aerosols over Southeastern Europe determined from UVRaman lidar measurements, Atmos. Chem. Phys., 9, 2431-2440, https://doi.org/10.5194/acp-9-2431-2009, 2009.

Ancellet, G., Pelon, J., Totems, J., Chazette, P., Bazureau, A., Sicard, M., Di Iorio, T., Dulac, F., and Mallet, M.: Longrange transport and mixing of aerosol sources during the 2013 North American biomass burning episode: analysis of multiple lidar observations in the western Mediterranean basin, Atmos. Chem. Phys., 16, 4725-4742, https://doi.org/10.5194/acp16-4725-2016, 2016.

Ansmann, A., Wagner, F., Althausen, D., Müller, D., Herber, A., and Wandinger, U.: European pollution outbreaks during ACE 2: Lofted aerosol plumes observed with Raman lidar at the Portuguese coast, J. Geophys. Res., 106, D18, https://doi.org/10.1029/2000JD000091, 2001.

Ansmann, A., Bösenberg, J., Chaikovsky, A., Comeròn, A., Eckhardt, S., Eixmann, R., Freudenthaler, V., Ginoux, P., Komguem, L., Linné, H., Márquez, M. A. L., Matthias, V., Mattis, I., Mitev, V., Müller, D., Music, S., Nickovic, S., Pelon, J., Sauvage, L., Sobolewsky, P., Srivastava, M., Stohl, A., Torres, O., Vaughan, G., Wandinger, U., and Wiegner, M.: Long-range transport of Saharan dust to northern Europe: The 11-16 October 2001 outbreak observed with EARLINET, J. Geophys. Res., 108, D24, https://doi.org/10.1029/2003JD003757, 2003.

Ansmann, A., Baars, H., Tesche, M., Müller, D., Althausen, D., Engelmann, R., Pauliquevis, T., and Artaxo, P.: Dust and smoke transport from Africa to South America: Lidar profiling over Cape Verde and the Amazon rainforest, Geophys. Res. Lett., 36, L11802, https://doi.org/10.1029/2009GL037923, 2009.

Ansmann, A., Tesche, M., Groß, S., Freudenthaler, V., Seifert, P., Hiebsch, A., Schmidt, J., Wandinger, U., Mattis, I., Müller, D., and Wiegner, M.: The 16 April 2010 major volcanic ash plume over central Europe: EARLINET lidar and AERONET photometer observations at Leipzig and Munich, Germany, Geophys. Res Lett., 37, L13810, https://doi.org/10.1029/2010GL043809, 2010.

Baars, H., Ansmann, A., Althausen, D., Engelmann, R., Heese, B., Müller, D., Artaxo, P., Paixao, M., Pauliquevis, M., and Souza, R.: Aerosol profiling with lidar in the Amazon Basin during the wet and dry season, J. Geophys. Res, 117, D21201, https://doi.org/10.1029/2012JD018338, 2012.

Baars, H., Kanitz, T., Engelmann, R., Althausen, D., Heese, B., Komppula, M., Preißler, J., Tesche, M., Ansmann, A., Wandinger, U., Lim, J.-H., Ahn, J. Y., Stachlewska, I. S., Amiridis, V., Marinou, E., Seifert, P., Hofer, J., Skupin, A., Schneider, F., Bohlmann, S., Foth, A., Bley, S., Pfüller, A., Giannakaki, E., Lihavainen, H., Viisanen, Y., Hooda, R. K., Pereira, S. N., Bortoli, D., Wagner, F., Mattis, I., Janicka, L., Markowicz, K. M., Achtert, P., Artaxo, P., Pauliquevis, T., Souza, R. A. F., Sharma, V. P., van Zyl, P. G., Beukes, J. P., Sun, J., Rohwer, E. G., Deng, R., Mamouri, R.-E., and Zamorano, F.: An overview of the first decade of PollyNET: an emerging network of automated 
Raman-polarization lidars for continuous aerosol profiling, Atmos. Chem. Phys., 16, 5111-5137, https://doi.org/10.5194/acp16-5111-2016, 2016.

Baklanov, A., Schlünzen, K., Suppan, P., Baldasano, J., Brunner, D., Aksoyoglu, S., Carmichael, G., Douros, J., Flemming, J., Forkel, R., Galmarini, S., Gauss, M., Grell, G., Hirtl, M., Joffre, S., Jorba, O., Kaas, E., Kaasik, M., Kallos, G., Kong, X., Korsholm, U., Kurganskiy, A., Kushta, J., Lohmann, U., Mahura, A., Manders-Groot, A., Maurizi, A., Moussiopoulos, N., Rao, S. T., Savage, N., Seigneur, C., Sokhi, R. S., Solazzo, E., Solomos, S., Sørensen, B., Tsegas, G., Vignati, E., Vogel, B., and Zhang, Y.: Online coupled regional meteorology chemistry models in Europe: current status and prospects, Atmos. Chem. Phys., 14, 317-398, https://doi.org/10.5194/acp-14-317-2014, 2014.

Balis, D., Amiridis, V., Nickovic, S., Papayannis, A., and Zerefos, C.: Raman lidar and sunphotometric measurements of aerosol optical properties over Thessaloniki, Greece during a biomass burning episode, Atmos. Environ., 31, 4529-4538, https://doi.org/10.1016/S1352-2310(03)00581-8, 2003.

Biele, J., Beyerle, G., and Baumgarten, G.: Polarization lidar: Corrections of instrumental effects, Opt. Exp., 7, 427-435, https://doi.org/10.1364/OE.7.000427, 2000.

Binietoglou, I., Basart, S., Alados-Arboledas, L., Amiridis, V., Argyrouli, A., Baars, H., Baldasano, J. M., Balis, D., Belegante, L., Bravo-Aranda, J. A., Burlizzi, P., Carrasco, V., Chaikovsky, A., Comerón, A., D’Amico, G., Filioglou, M., Granados-Muñoz, M. J., Guerrero-Rascado, J. L., Ilic, L., Kokkalis, P., Maurizi, A., Mona, L., Monti, F., Muñoz-Porcar, C., Nicolae, D., Papayannis, A., Pappalardo, G., Pejanovic, G., Pereira, S. N., Perrone, M. R., Pietruczuk, A., Posyniak, M., Rocadenbosch, F., Rodríguez-Gómez, A., Sicard, M., Siomos, N., Szkop, A., Terradellas, E., Tsekeri, A., Vukovic, A., Wandinger, U., and Wagner, J.: A methodology for investigating dust model performance using synergistic EARLINET/AERONET dust concentration retrievals, Atmos. Meas. Tech., 8, 3577-3600, https://doi.org/10.5194/amt-8-3577-2015, 2015.

Bovchaliuk, V., Goloub, P., Podvin, T., Veselovskii, I., Tanre, D., Chaikovsky, A., Dubovik, O., Mortier, A., Lopatin, A., Korenskiy, M., and Victori, S.: Comparison of aerosol properties retrieved using GARRLiC, LIRIC, and Raman algorithms applied to multi-wavelength lidar and sun/sky-photometer data, Atmos. Meas. Tech., 9, 3391-3405, https://doi.org/10.5194/amt-9-33912016, 2016.

Bravo-Aranda, J. A., Titos, G., Granados-Muñoz, M., GuerreroRascado, J., Navas-Guzmán, F., Valenzuela, A., Lyamani, H., Olmo, F., Andrey, J., and Alados-Arboledas, L.: Study of mineral dust entrainment in the planetary boundary layer by lidar depolarisation technique, Tellus B, 67, 26180, https://doi.org/10.3402/tellusb.v67.26180, 2015.

Burton, S. P., Ferrare, R. A., Hostetler, C. A., Hair, J. W., Rogers, R. R., Obland, M. D., Butler, C. F., Cook, A. L., Harper, D. B., and Froyd, K. D.: Aerosol classification using airborne High Spectral Resolution Lidar measurements - methodology and examples, Atmos. Meas. Tech., 5, 73-98, https://doi.org/10.5194/amt-5-732012, 2012.

Burton, S. P., Ferrare, R. A., Vaughan, M. A., Omar, A. H., Rogers, R. R., Hostetler, C. A., and Hair, J. W.: Aerosol classification from airborne HSRL and comparisons with the
CALIPSO vertical feature mask, Atmos. Meas. Tech., 6, 13971412, https://doi.org/10.5194/amt-6-1397-2013, 2013.

Burton, S. P., Vaughan, M. A., Ferrare, R. A., and Hostetler, C. A.: Separating mixtures of aerosol types in airborne High Spectral Resolution Lidar data, Atmos. Meas. Tech., 7, 419-436, https://doi.org/10.5194/amt-7-419-2014, 2014.

Burton, S. P., Hair, J. W., Kahnert, M., Ferrare, R. A., Hostetler, C. A., Cook, A. L., Harper, D. B., Berkoff, T. A., Seaman, S. T., Collins, J. E., Fenn, M. A., and Rogers, R. R.: Observations of the spectral dependence of linear particle depolarization ratio of aerosols using NASA Langley airborne High Spectral Resolution Lidar, Atmos. Chem. Phys., 15, 13453-13473, https://doi.org/10.5194/acp-15-13453-2015, 2015.

Cattrall, C., Reagan, J., Thome, K., and Dubovik, O.: Variability of aerosol and spectral lidar and backscatter and extinction ratios of key aerosol types derived from selected Aerosol Robotic Network locations, J. Geophys. Res., 110, D10S11, https://doi.org/10.1029/2004JD005124, 2005.

Chaikovsky, A., Dubovik, O., Holben, B., Bril, A., Goloub, P., Tanré, D., Pappalardo, G., Wandinger, U., Chaikovskaya, L., Denisov, S., Grudo, J., Lopatin, A., Karol, Y., Lapyonok, T., Amiridis, V., Ansmann, A., Apituley, A., Allados-Arboledas, L., Binietoglou, I., Boselli, A., D’Amico, G., Freudenthaler, V., Giles, D., Granados-Muñoz, M. J., Kokkalis, P., Nicolae, D., Oshchepkov, S., Papayannis, A., Perrone, M. R., Pietruczuk, A., Rocadenbosch, F., Sicard, M., Slutsker, I., Talianu, C., De Tomasi, F., Tsekeri, A., Wagner, J., and Wang, X.: Lidar-Radiometer Inversion Code (LIRIC) for the retrieval of vertical aerosol properties from combined lidar/radiometer data: development and distribution in EARLINET, Atmos. Meas. Tech., 9, 1181-1205, https://doi.org/10.5194/amt-9-1181-2016, 2016.

Córdoba-Jabonero, C., Sorribas, M., Guerrero-Rascado, J. L., Adame, J. A., Hernández, Y., Lyamani, H., Cachorro, V., Gil, M., Alados-Arboledas, L., Cuevas, E., and de la Morena, B.: Synergetic monitoring of Saharan dust plumes and potential impact on surface: a case study of dust transport from Canary Islands to Iberian Peninsula, Atmos. Chem. Phys., 11, 3067-3091, https://doi.org/10.5194/acp-11-3067-2011, 2011.

D’Amico, G., Amodeo, A., Baars, H., Binietoglou, I., Freudenthaler, V., Mattis, I., Wandinger, U., and Pappalardo, G.: EARLINET Single Calculus Chain - overview on methodology and strategy, Atmos. Meas. Tech., 8, 4891-4916, https://doi.org/10.5194/amt-8-4891-2015, 2015.

Dawson, K. W., Meskhidze, N., Josset, D., and Gassó, S.: Spaceborne observations of the lidar ratio of marine aerosols, Atmos. Chem. Phys., 15, 3241-3255, https://doi.org/10.5194/acp15-3241-2015, 2015.

EARLINET publishing group 2000-2010: EARLINET Correlative Observations for CALIPSO (2006-2010), World Data Center for Climate (WDCC), Hamburg, Germany, https://doi.org/10.1594/WDCC/EN_Calipso_2006-2010, 2014a.

EARLINET publishing group 2000-2010: EARLINET observations related to Saharan Dust events (2000-2010), World Data Center for Climate (WDCC), Hamburg, Germany, https://doi.org/10.1594/WDCC/EARLINET_SaharanDust_20002010, 2014b.

EARLINET publishing group 2000-2010: EARLINET observations related to volcanic eruptions (2000-2010), World Data Center for Climate (WDCC), Hamburg, Germany, 
https://doi.org/10.1594/WDCC/EN_VolcanicEruption_20002010, 2014c.

EARLINET publishing group 2000-2010: EARLINET climatology (2000-2010), World Data Center for Climate (WDCC), Hamburg, Germany, https://doi.org/10.1594/WDCC/EN_Climatology_2000-2010, 2014d.

EARLINET publishing group 2000-2015: EARLINET All 20002015, World Data Center for Climate (WDCC), in press, 2018a.

EARLINET publishing group 2000-2015: EARLINET Calipso 2000-2015, World Data Center for Climate (WDCC), in press, $2018 b$.

EARLINET publishing group 2000-2015: EARLINET Saharan Dust 2000-2015, World Data Center for Climate (WDCC), in press, 2018c.

EARLINET publishing group 2000-2015: EARLINET Climatology 2000-2015, World Data Center for Climate (WDCC), in press, $2018 \mathrm{~d}$.

EARLINET publishing group 2000-2015: EARLINET Volcanic Eruption 2000-2015, World Data Center for Climate (WDCC), in press, $2018 \mathrm{e}$.

Freudenthaler, V., Esselborn, M., Wiegner, M., Heese, B., Tesche, M., Ansmann, A., Müller, D., Althausen, D., Wirth, M., Fix, A., Ehret, G., Knippertz, P., Toledano, C., Gasteiger, J., Garhammer, M., and Seefeldner, M.: Depolarization ratio profiling at several wavelengths in pure Saharan dust during SAMUM 2006, Tellus B, 61, 165-179, https://doi.org/10.1111/j.16000889.2008.00396.x, 2009.

Giannakaki, E., Balis, D. S., Amiridis, V., and Zerefos, C.: Optical properties of different aerosol types: seven years of combined Raman-elastic backscatter lidar measurements in Thessaloniki, Greece, Atmos. Meas. Tech., 3, 569-578, https://doi.org/10.5194/amt-3-569-2010, 2010.

Giannakaki, E., van Zyl, P. G., Müller, D., Balis, D., and Komppula, M.: Optical and microphysical characterization of aerosol layers over South Africa by means of multi-wavelength depolarization and Raman lidar measurements, Atmos. Chem. Phys., 16, 81098123, https://doi.org/10.5194/acp-16-8109-2016, 2016.

Ginoux, P., Chin, M., Tegen, I., Prospero, J. M., Holben, B., Dubovik, O., and Lin, S.-J.: Sources and distributions of dust aerosols simulated with the GOCART model, J. Geophys. Res., 20, 20255-20274, https://doi.org/10.1029/2000JD000053, 2001.

Ginoux, P., Prospero, J. M., Gill, T. E., Hsu, N. C., and Zhao, M.: Global-scale attribution of anthropogenic and natural dust sources and their emission rates based on MODIS Deep Blue aerosol products, Rev. Geophys., 50, RG3005, https://doi.org/10.1029/2012RG000388, 2012.

Granados-Muñoz, M. J., Bravo-Aranda, J. A., Baumgardner, D., Guerrero-Rascado, J. L., Pérez-Ramírez, D., Navas-Guzmán, F., Veselovskii, I., Lyamani, H., Valenzuela, A., Olmo, F. J., Titos, G., Andrey, J., Chaikovsky, A., Dubovik, O., Gil-Ojeda, M., and Alados-Arboledas, L.: A comparative study of aerosol microphysical properties retrieved from ground-based remote sensing and aircraft in situ measurements during a Saharan dust event, Atmos. Meas. Tech., 9, 1113-1133, https://doi.org/10.5194/amt9-1113-2016, 2016a.

Granados-Muñoz, M. J., Navas-Guzmán, F., Guerrero-Rascado, J. L., Bravo-Aranda, J. A., Binietoglou, I., Pereira, S. N., Basart, S., Baldasano, J. M., Belegante, L., Chaikovsky, A., Com- erón, A., D’Amico, G., Dubovik, O., Ilic, L., Kokkalis, P., Muñoz-Porcar, C., Nickovic, S., Nicolae, D., Olmo, F. J., Papayannis, A., Pappalardo, G., Rodríguez, A., Schepanski, K., Sicard, M., Vukovic, A., Wandinger, U., Dulac, F., and AladosArboledas, L.: Profiling of aerosol microphysical properties at several EARLINET/AERONET sites during the July 2012 ChArMEx/EMEP campaign, Atmos. Chem. Phys., 16, 70437066, https://doi.org/10.5194/acp-16-7043-2016, 2016 b.

Groß, S., Tesche, M., Freudenthaler, V., Toledano, C., Wiegner, M., Althausen, D., and Seefeldner, M.: Characterization of Saharan dust, marine aerosols and mixtures of biomass-burning aerosols and dust by means of multi-wavelength depolarization and Raman lidar measurements during SAMUM 2, Tellus B, 63, 706724, https://doi.org/10.3402/tellusb.v63i4.16369, 2011.

Groß, S., Esselborn, M., Weinzierl, B., Wirth, M., Fix, A., and Petzold, A.: Aerosol classification by airborne high spectral resolution lidar observations, Atmos. Chem. Phys., 13, 2487-2505, https://doi.org/10.5194/acp-13-2487-2013, 2013.

Groß, S., Gasteiger, J., Freudenthaler, V., Müller, T., Sauer, D., Toledano, C., and Ansmann, A.: Saharan dust contribution to the Caribbean summertime boundary layer - a lidar study during SALTRACE, Atmos. Chem. Phys., 16, 11535-11546, https://doi.org/10.5194/acp-16-11535-2016, 2016.

Guerrero-Rascado, J. L., Ruiz, B., and Alados-Arboledas, L.: Multispectral Lidar characterization of the vertical structure of Saharan dust aerosol over southern Spain, Atmos. Environ., 42, 2668 2681, https://doi.org/10.1016/j.atmosenv.2007.12.062, 2008.

Guerrero-Rascado, J. L., Olmo, F. J., Avilés-Rodríguez, I., NavasGuzmán, F., Pérez-Ramírez, D., Lyamani, H., and Alados Arboledas, L.: Extreme Saharan dust event over the southern Iberian Peninsula in september 2007: active and passive remote sensing from surface and satellite, Atmos. Chem. Phys., 9, 84538469, https://doi.org/10.5194/acp-9-8453-2009, 2009.

Hamill, P., Giordano, M., Ward, C., Giles, D., and Holben, B.: An AERONET-based aerosol classification using the Mahalanobis distance, Atmos. Environ., 140, 213-233, https://doi.org/10.1016/j.atmosenv.2016.06.002, 2016.

Heese, B., Althausen, D., Baars, H., Bohlmann, S., and Deng, R.: Aerosol Properties over Southeastern China from Multi-Wavelength Raman and Depolarization Lidar Measurements, EPJ Web of Conferences, 119, 23018, https://doi.org/10.1051/epjconf/201611923018, 2016.

Holben, B., Eck, T., Slutsker, I., Tanré, D., Buis, J., Setzer, A., Vermote, E., Reagan, J., Kaufman, Y., Nakajima, T., Lavenu, F., Jankowiak, I., and Smirnov, A.: AERONET-A Federated Instrument Network and Data Archive for Aerosol Characterization, Remote Sens. Environ., 66, 0034-4257, https://doi.org/10.1016/S0034-4257(98)00031-5, 1998.

Iarlori, M., Madonna, F., Rizi, V., Trickl, T., and Amodeo, A.: Effective resolution concepts for lidar observations, Atmos. Meas. Tech., 8, 5157-5176, https://doi.org/10.5194/amt-8-5157-2015, 2015.

Kim, M.-H., Kim, S.-W., Yoon, S.-C., and Omar, A. H.: Comparison of aerosol optical depth between CALIOP and MODIS-Aqua for CALIOP aerosol subtypes over the ocean, J. Geophys. Res.-Atmos., 118, 13,241-13,252, https://doi.org/10.1002/2013JD019527, 2013.

Kokkalis, P., Papayannis, A., Amiridis, V., Mamouri, R. E., Veselovskii, I., Kolgotin, A., Tsaknakis, G., Kristiansen, N. 
I., Stohl, A., and Mona, L.: Optical, microphysical, mass and geometrical properties of aged volcanic particles observed over Athens, Greece, during the Eyjafjallajökull eruption in April 2010 through synergy of Raman lidar and sunphotometer measurements, Atmos. Chem. Phys., 13, 9303-9320, https://doi.org/10.5194/acp-13-9303-2013, 2013.

Liu, D., Wang, Z., Liu, Z., Winker, D., and Trepte, C.: A height resolved global view of dust aerosols from the first year CALIPSO lidar measurements, J. Geophys. Res., 113, D16214, https://doi.org/10.1029/2007JD009776, 2008.

Madonna, F., Amato, F., Vande Hey, J., and Pappalardo, G.: Ceilometer aerosol profiling versus Raman lidar in the frame of the INTERACT campaign of ACTRIS, Atmos. Meas. Tech., 8, 2207-2223, https://doi.org/10.5194/amt-8-2207-2015, 2015.

Mahalanobis, P. C.: On the generalized distance in statistics, in: Proceedings of the National Institute of Science of India, 49-55, 1936.

Mahowald, N., Albani, S., Kok, J. F., Engelstaeder, S., Scanza, R., Ward, D. S., and Flanner, M. G.: The size distribution of desert dust aerosols and its impact on the Earth system, Aeolian Res., 15, 53-71, https://doi.org/10.1016/j.aeolia.2013.09.002, 2014.

Mamouri, R. E., Amiridis, V., Papayannis, A., Giannakaki, E., Tsaknakis, G., and Balis, D. S.: Validation of CALIPSO spaceborne-derived attenuated backscatter coefficient profiles using a ground-based lidar in Athens, Greece, Atmos. Meas. Tech., 2, 513-522, https://doi.org/10.5194/amt-2-513-2009, 2009.

Mamouri, R. E., Ansmann, A., Nisantzi, A., Kokkalis, P., Schwarz, A., and Hadjimitsis, D.: Low Arabian dust extinctionto-backscatter ratio, Geophys. Res. Lett., 40, 4762-4766, https://doi.org/10.1002/grl.50898, 2013.

Mattis, I., Siefert, P., Müller, D., Tesche, M., Hiebsch, A., Kanitz, T., Schmidt, J., Finger, F., Wandinger, U., and Ansmann, A.: Volcanic aerosol layers observed with multiwavelength Raman lidar over central Europe in 2008-2009, J. Geophys. Res.-Atmos., 115, D00L04, https://doi.org/10.1029/2009JD013472, 2010.

Mona, L. and Marenco, F.: Volcanic Ash: Hazard Observation, chap. Lidar Observations of Volcanic Particles, Elsevier, 161173, 2016.

Mona, L., Amodeo, A., Pandolfi, M., and Pappalardo, G.: Saharan dust intrusions in the Mediterranean area: Three years of Raman lidar measurements, J. Geophys. Res.-Atmos., 111, D16203, https://doi.org/10.1029/2005JD006569, 2006.

Mona, L., Pappalardo, G., Amodeo, A., D’Amico, G., Madonna, F., Boselli, A., Giunta, A., Russo, F., and Cuomo, V.: One year of CNR-IMAA multi-wavelength Raman lidar measurements in coincidence with CALIPSO overpasses: Level 1 products comparison, Atmos. Chem. Phys., 9, 7213-7228, https://doi.org/10.5194/acp-9-7213-2009, 2009.

Mona, L., Amodeo, A., D’Amico, G., Giunta, A., Madonna, F., and Pappalardo, G.: Multi-wavelength Raman lidar observations of the Eyjafjallajökull volcanic cloud over Potenza, southern Italy, Atmos. Chem. Phys., 12, 2229-2244, https://doi.org/10.5194/acp-12-2229-2012, 2012. 2012a.

Mona, L., Liu, Z., Müller, D., Omar, A., Papayannis, A., Sugimoto, N., Pappalardo, G., and Vaughan, M.: Measurements for Desert Dust Characterization: An Overview, Adv. Meteorol., 2012, 356265, https://doi.org/10.1155/2012/356265, 2012b.

Mona, L., Papagiannopoulos, N., Basart, S., Baldasano, J., Binietoglou, I., Cornacchia, C., and Pappalardo, G.: EARLINET dust observations vs. BSC-DREAM8b modeled profiles: 12year-long systematic comparison at Potenza, Italy, Atmos. Chem. Phys., 14, 8781-8793, https://doi.org/10.5194/acp-148781-2014, 2014.

Müller, D., Mattis, I., Ansmann, A., Wehner, B., Althausen, D., Wandinger, U., and Dubovik, O.: Closure study on optical and microphysical properties of a mixed urban and Arctic haze air mass observed with Raman lidar and Sun photometer, J. Geophys. Res.-Atmos., 109, D13206, https://doi.org/10.1029/2003JD004200, 2004.

Müller, D., Mattis, I., Wandinger, U., Ansmann, A., Althausen, D., and Stohl, A.: Raman lidar observations of aged Siberian and Canadian forest fire smoke in the free troposphere over Germany in 2003: Microphysical particle characterization, J. Geophys. Res., 110, D17201, https://doi.org/10.1029/2004JD005756, 2005.

Müller, D., Ansmann, A., Mattis, I., Tesche, M., Wandinger, U., Althausen, D., and Pisani, G.: Aerosol-type-dependent lidar ratios observed with Raman lidar, J. Geophys. Res., 112, D16202, https://doi.org/10.1029/2006JD008292, 2007a.

Müller, D., Mattis, I., Ansmann, A., Wandinger, U., Ritter, C., and Kaiser, D.: Multiwavelength Raman lidar observations of particle growth during long-range transport of forest-fire smoke in the free troposphere, Geophys. Res. Lett., 34, L05803, https://doi.org/10.1029/2006GL027936, 2007b.

Müller, D., Heinold, B., Tesche, M., Tegen, I., Althausen, D., Alados-Arboledas, L., Amiridis, V., Amodeo, A., Ansmann, A., Balis, D., Comeron, A., D’Amico, G., Gerasopoulos, E., Guerrero-Rascado, J. L., Freudenthaler, V., Giannakaki, E., Heese, B., Iarlori, M., Knippertz, P., Mamouri, R. E., Mona, L., Papayannis, A., Pappalardo, G., Perrone, R.-M., Pisani, G., Rizi, V., Sicard, M., Spinelli, N., Tafuro, A., and Wiegner, M.: EARLINET observations of the 14-22-May long-range dust transport event during SAMUM 2006: validation of results from dust transport modelling, Tellus B, 61, 325-339, https://doi.org/10.1111/j.1600-0889.2008.00400.x, 2009.

Navas-Guzmán, F., Müller, D., Bravo-Aranda, J. A., GuerreroRascado, J. L., Granados-Muñoz, M. J., Pérez-Ramírez, D., Olmo, F. J., and Alados-Arboledas, L.: Eruption of the Eyjafjallajökull Volcano in spring 2010: Multiwavelength Raman lidar measurements of sulphate particles in the lower troposphere, J. Geophys. Res.-Atmos., 118, 1804-1813, https://doi.org/10.1002/jgrd.50116, 2013a.

Navas-Guzmán, N., Bravo-Aranda, J. A., Guerrero-Rascado, J. L., Granados-Muñoz, M. J., and Alados-Arboledas, L.: Statistical analysis of aerosol optical properties retrieved by Raman lidar over Southeastern Spain, Tellus B, 65, 21234, https://doi.org/10.3402/tellusb.v65i0.21234, 2013b.

Nepomuceno Pereira, S., Preißler, J., Guerrero-Rascado, J. L., Silva, A. M., and Wagner, F.: Forest Fire Smoke Layers Observed in the Free Troposphere over Portugal with a Multiwavelength Raman Lidar: Optical and Microphysical Properties, Scientific World Journal, 2014, 421838, https://doi.org/10.1155/2014/421838, 2014.

Nicolae, D., Nemuc, A., Müller, D., Talianu, C., Vasilescu, J., Belegante, L., and Kolgotin, A.: Characterization of fresh and aged biomass burning events using multiwavelength Raman lidar and mass spectrometry, J. Geophys. Res.-Atmos., 118, 2956-2965, https://doi.org/10.1002/jgrd.50324, 2013. 
Nicolae, D., Vasilescu, J., Talianu, C., and Dandocsi, A.: Independent Retrieval of Aerosol Type From Lidar, EPJ Web of Conferences, 119, 18002, https://doi.org/10.1051/epjconf/201611918002, 2016.

Nisantzi, A., Mamouri, R. E., Ansmann, A., Schuster, G. L., and Hadjimitsis, D. G.: Middle East versus Saharan dust extinctionto-backscatter ratios, Atmos. Chem. Phys., 15, 7071-7084, https://doi.org/10.5194/acp-15-7071-2015, 2015.

O'Dowd, C. and de Leeuw, G.: Marine aerosol production: a review of the current knowledge, Philos. T. Roy. Soc. A, https://doi.org/10.1098/rsta.2007.2043, 2007.

Omar, A., Winker, D., Kittaka, C., Vaughan, M., Liu, Z., Hu, X., Trepte, C., Rogers, R., Ferrare, R., Lee, K., Kuehn, R., and Hostetler, C.: The CALIPSO Automated Aerosol Classification and Lidar Ratio Selection Algorithm, J. Atmos. Ocean. Tech., 26, 1994-2014, https://doi.org/10.1175/2009JTECHA1231.1, 2009.

Ortiz-Amezcua, P., Guerrero-Rascado, J. L., Granados-Muñoz, M. J., Benavent-Oltra, J. A., Böckmann, C., Samaras, S., Stachlewska, I. S., Janicka, L., Baars, H., Bohlmann, S., and AladosArboledas, L.: Microphysical characterization of long-range transported biomass burning particles from North America at three EARLINET stations, Atmos. Chem. Phys., 17, 5931-5946, https://doi.org/10.5194/acp-17-5931-2017, 2017.

Papagiannopoulos, N., Mona, L., Alados-Arboledas, L., Amiridis, V., Baars, H., Binietoglou, I., Bortoli, D., D'Amico, G., Giunta, A., Guerrero-Rascado, J. L., Schwarz, A., Pereira, S., Spinelli, N., Wandinger, U., Wang, X., and Pappalardo, G.: CALIPSO climatological products: evaluation and suggestions from EARLINET, Atmos. Chem. Phys., 16, 2341-2357, https://doi.org/10.5194/acp-16-2341-2016, 2016a.

Papagiannopoulos, N., Mona, L., and Pappalardo, G.: Aerosol classification using EARLINET measurements for an intensive observational period, vol. 18, European Geosciences Union, General Assembly, 2016b.

Papayannis, A., Amiridis, V., Mona, L., Tsaknakis, G., Balis, D., Bösenberg, J., Chaikovski, A., De Tomasi, F., Grigorov, I., Mattis, I., Mitev, V., Müller, D., Nickovic, S., Pérez, C., Pietruczuk, A., Pisani, G., Ravetta, F., Rizi, V., Sicard, M., Trickl, T., Wiegner, M., Gerding, M., Mamouri, R. E., D'Amico, G., and Pappalardo, G.: Systematic lidar observations of Saharan dust over Europe in the frame of EARLINET (2000-2002), J. Geophys. Res., 113, D10204, https://doi.org/10.1029/2007JD009028, 2008.

Papayannis, A., Mamouri, R. E., Amiridis, V., Giannakaki, E., Veselovskii, I., Kokkalis, P., Tsaknakis, G., Balis, D., Kristiansen, N., Stohl, A., Korenskiy, M., Allakhverdiev, K., Huseyinoglu, M., and Baykara, T.: Optical properties and vertical extension of aged ash layers over the Eastern Mediterranean as observed by Raman lidars during the Eyjafjallajökull eruption in May 2010, Atmos. Environ., 48, 56-65, https://doi.org/10.1016/j.atmosenv.2011.08.037, 2012.

Papayannis, A., Nicolae, D., Kokkalis, P., Binietoglou, I., Talianu, C., Belegante, L., Tsaknakis, G., Cazacu, M., Vetres, I., and Ilic, L.: Optical, size and mass properties of mixed type aerosols in Greece and Romania as observed by synergy of lidar and sunphotometers in combination with model simulations: A case study, Sci. Total Environ., 500-501, 277-297, https://doi.org/10.1016/j.scitotenv.2014.08.101, 2014.
Papayannis, A., Argyrouli, A., Müller, D., Tsaknakis, G., Kokkalis, P., Binietoglou, I., Kazadzis, S., Solomos, S., and Amiridis, V.: Tropospheric Vertical Profiles of Aerosol Optical, Microphysical and Concentration Properties in the Frame of the Hygra-CD Campaign (Athens, Greece 2014): A Case Study of Long-Range Transport of Mixed Aerosols, EPJ Web of Conferences, 119 , 23016, https://doi.org/10.1051/epjconf/201611923016, 2016.

Pappalardo, G., Amodeo, A., Mona, L., Pandolfi, M., Pergola, N., and Cuomo, V.: Raman lidar observations of aerosol emitted during the 2002 Etna eruption, Geophys. Res. Lett., 31, L05120, https://doi.org/10.1029/2003GL019073, 2004a.

Pappalardo, G., Amodeo, A., Pandolfi, M., Wandinger, U., Ansmann, A., Bösenberg, J., Matthias, V., Amiridis, V., De Tomasi, F., Frioud, M., Iarlori, M., Komguem, L., Papayannis, A., Rocadenbosch, F., and Wang, X.: Aerosol lidar intercomparison in the framework of the EARLINET project. 3. Ramanlidar algorithm for aerosol extinction, backscatter, and lidar ratio, Appl. Opt., 43, 5370-5385, https://doi.org/10.1364/AO.43.005370, 2004b.

Pappalardo, G., Mona, L., D’Amico, G., Wandinger, U., Adam, M., Amodeo, A., Ansmann, A., Apituley, A., Alados Arboledas, L., Balis, D., Boselli, A., Bravo-Aranda, J. A., Chaikovsky, A., Comeron, A., Cuesta, J., De Tomasi, F., Freudenthaler, V., Gausa, M., Giannakaki, E., Giehl, H., Giunta, A., Grigorov, I., Groß, S., Haeffelin, M., Hiebsch, A., Iarlori, M., Lange, D., Linné, H., Madonna, F., Mattis, I., Mamouri, R.-E., McAuliffe, M. A. P., Mitev, V., Molero, F., Navas-Guzman, F., Nicolae, D., Papayannis, A., Perrone, M. R., Pietras, C., Pietruczuk, A., Pisani, G., Preißler, J., Pujadas, M., Rizi, V., Ruth, A. A., Schmidt, J., Schnell, F., Seifert, P., Serikov, I., Sicard, M., Simeonov, V., Spinelli, N., Stebel, K., Tesche, M., Trickl, T., Wang, X., Wagner, F., Wiegner, M., and Wilson, K. M.: Four-dimensional distribution of the 2010 Eyjafjallajökull volcanic cloud over Europe observed by EARLINET, Atmos. Chem. Phys., 13, 4429-4450, https://doi.org/10.5194/acp-13-4429-2013, 2013.

Pappalardo, G., Amodeo, A., Apituley, A., Comeron, A., Freudenthaler, V., Linné, H., Ansmann, A., Bösenberg, J., D’Amico, G., Mattis, I., Mona, L., Wandinger, U., Amiridis, V., AladosArboledas, L., Nicolae, D., and Wiegner, M.: EARLINET: towards an advanced sustainable European aerosol lidar network, Atmos. Meas. Tech., 7, 2389-2409, https://doi.org/10.5194/amt7-2389-2014, 2014.

Prata, F., Woodhouse, M., Huppert, H. E., Prata, A., Thordarson, T., and Carn, S.: Atmospheric processes affecting the separation of volcanic ash and $\mathrm{SO}_{2}$ in volcanic eruptions: inferences from the May 2011 Grímsvötn eruption, Atmos. Chem. Phys., 17, 1070910732, https://doi.org/10.5194/acp-17-10709-2017, 2017.

Preißler, J., Wagner, F., Pereira, S. N., and Guerrero-Rascado, J. L.: Multi-instrumental observation of an exceptionally strong Saharan dust outbreak over Portugal, J. Geophys. Res.-Atmos., 116, D24204, https://doi.org/10.1029/2011JD016527, 2011.

Preißler, J., Wagner, F., Guerrero-Rascado, J. L., and Silva, A. M.: Two years of free-tropospheric aerosol layers observed over Portugal by lidar, J. Geophys. Res.-Atmos., 118, 3676-3686, https://doi.org/10.1002/jgrd.50350, 2013.

Rencher, A.: Methods of Multivariate Analysis, Wiley-Interscience, 2002.

Rogers, R. R., Vaughan, M. A., Hostetler, C. A., Burton, S. P., Ferrare, R. A., Young, S. A., Hair, J. W., Obland, M. D., Harper, D. B., Cook, A. L., and Winker, D. M.: Looking through the haze: 
evaluating the CALIPSO level 2 aerosol optical depth using airborne high spectral resolution lidar data, Atmos. Meas. Tech., 7, 4317-4340, https://doi.org/10.5194/amt-7-4317-2014, 2014.

Russell, P. B., Kacenelenbogen, M., Livingston, J. M., Hasekamp, O. P., Burton., S. P., Schuster, G. L., Johnson, M. S., Knobelspiesse, K. D., Redemann, J., Ramachandran, S., and Holben, B.: A multiparameter aerosol classification method and its application to retrievals from spaceborne polarimetry, J. Geophys. Res.-Atmos., 119, 9838-9863, https://doi.org/10.1002/2013JD021411, 2014.

Sawamura, P., Vernier, J. P., Barnes, J. E., Berkoff, T. E., Welton, E. J., Alados-Arboledas, L., Navas-Guzmán, F., Pappalardo, G., Mona, L., Madonna, F., Lange, D., Sicard, M., GodinBeekmann, S., Payen, G., Wang, Z., Hu, S., Tripathi, S. N., Cordoba-Jabonero, C., and Hoff, R. M.: Stratospheric AOD after the 2011 eruption of Nabro volcano measured by lidars over the Northern Hemisphere, Environ. Res. Lett., 7, 034013, https://doi.org/10.1088/1748-9326/7/3/034013, 2012.

Schuster, G. L., Vaughan, M., MacDonnell, D., Su, W., Winker, D., Dubovik, O., Lapyonok, T., and Trepte, C.: Comparison of CALIPSO aerosol optical depth retrievals to AERONET measurements, and a climatology for the lidar ratio of dust, Atmos. Chem. Phys., 12, 7431-7452, https://doi.org/10.5194/acp12-7431-2012, 2012.

Schwarz, A.: Aerosol typing over Europe and its benefits for the CALIPSO and EarthCARE missions - statistical analysis based on multiwavelength aerosol lidar measurements from ground-based EARLINET stations and comparison to spaceborne CALIPSO data, PhD thesis, University of Leipzig, 2016.

Sicard, M., Guerrero-Rascado, J. L., Navas-Guzmán, F., Preißler, J., Molero, F., Tomás, S., Bravo-Aranda, J. A., Comerón, A., Rocadenbosch, F., Wagner, F., Pujadas, M., and AladosArboledas, L.: Monitoring of the Eyjafjallajökull volcanic aerosol plume over the Iberian Peninsula by means of four EARLINET lidar stations, Atmos. Chem. Phys., 12, 3115-3130, https://doi.org/10.5194/acp-12-3115-2012, 2012a.

Sicard, M., Mallet, M. García-Vizcaíno, D., Comerón, A., Rocadenbosch, F., Dubuisson, P., and Muñoz Porcar, C.: Intense dust and extremely fresh biomass burning outbreak in Barcelona, Spain: characterization of their optical properties and estimation of their direct radiative forcing, Environ. Res. Lett., 7, 034016, https://doi.org/10.1088/1748-9326/7/3/034016, 2012b.

Sicard, M., D’Amico, G., Comerón, A., Mona, L., AladosArboledas, L., Amodeo, A., Baars, H., Baldasano, J. M., Belegante, L., Binietoglou, I., Bravo-Aranda, J. A., Fernández, A. J., Fréville, P., García-Vizcaíno, D., Giunta, A., Granados-Muñoz, M. J., Guerrero-Rascado, J. L., Hadjimitsis, D., Haefele, A., Hervo, M., Iarlori, M., Kokkalis, P., Lange, D., Mamouri, R. E., Mattis, I., Molero, F., Montoux, N., Muñoz, A., Muñoz Porcar, C., Navas-Guzmán, F., Nicolae, D., Nisantzi, A., Papagiannopoulos, N., Papayannis, A., Pereira, S., Preißler, J., Pujadas, M., Rizi, V., Rocadenbosch, F., Sellegri, K., Simeonov, V., Tsaknakis, G., Wagner, F., and Pappalardo, G.: EARLINET: potential operationality of a research network, Atmos. Meas. Tech., 8, 4587-4613, https://doi.org/10.5194/amt-8-4587-2015, 2015.

Stohl, A., Forster, C., Frank, A., Seibert, P., and Wotawa, G.: Technical note: The Lagrangian particle dispersion model FLEXPART version 6.2, Atmos. Chem. Phys., 5, 2461-2474, https://doi.org/10.5194/acp-5-2461-2005, 2005.
Tanré, D., Bréon, F. M., Deuzé, J. L., Dubovik, O., Ducos, F., François, P., Goloub, P., Herman, M., Lifermann, A., and Waquet, F.: Remote sensing of aerosols by using polarized, directional and spectral measurements within the A-Train: the PARASOL mission, Atmos. Meas. Tech., 4, 1383-1395, https://doi.org/10.5194/amt-4-1383-2011, 2011.

Tesche, M., Müller, D., Groß, S., Ansmann, A., Althausen, D., Freudenthaler, V., Weinzierl, B., Veira, A., and Petzold, A.: Optical and microphysical properties of smoke over Cape Verde inferred from multiwavelength lidar measurements, Tellus B, 63, 677-694, https://doi.org/10.1111/j.1600-0889.2011.00549.x, 2011.

Tesche, M., Wandinger, U., Ansmann, A., Althausen, D., Müller, D., and Omar, A. H.: Ground-based validation of CALIPSO observations of dust and smoke in the Cape Verde region, J. Geophys. Res.-Atmos., 118, 2889-2902, https://doi.org/10.1002/jgrd.50248, 2013.

Valenzuela, A., Olmo, F. J., Lyamani, H., Antón, M., Quirantes, A., and Alados-Arboledas, L.: Classification of aerosol radiative properties during African desert dust intrusions over southeastern Spain by sector origins and cluster analysis, J. Geophys. Res.Atmos., 117, D06214, https://doi.org/10.1029/2011JD016885, 2012.

Valenzuela, A., Olmo, F. J., Lyamani, H., Granados-Muñoz, M. J., Antón, M., Guerrero-Rascado, J. L., Quirantes, A., Toledano, C., Perez-Ramírez, D., and Alados-Arboledas, L.: Aerosol transport over the western Mediterranean basin: Evidence of the contribution of fine particles to desert dust plumes over Alborán Island, J. Geophys. Res.-Atmos., 119, 14028-14044, https://doi.org/10.1002/2014JD022044, 2014.

Veselovskii, I., Dubovik, O., Kolgotin, A., Lapyonok, T., Di Girolamo, P., Summa, D., Whiteman, D. N., Mishchenko, M., and Tanré, D.: Application of randomly oriented spheroids for retrieval of dust particle parameters from multiwavelength lidar measurements, J. Geophys. Res., 115, D21203, https://doi.org/10.1029/2010JD014139, 2010.

Wandinger, U., Baars, H., Engelmann, R., Hünerbein, A., Horn, S., Kanitz, T., Donovan, D., van Zadelhoff, G.-J., Daou, D., Fischer, J., von Bismarck, J., Filipitsch, F., Docter, N., Eisinger, M., Lajas, D., and Wehr, T.: HETEAC: The Aerosol Classification Model for EarthCARE, EPJ Web of Conferences, 119, 01004, https://doi.org/10.1051/epjconf/201611901004, 2016.

Wang, X., Boselli, A., D’Avino, L., Pisani, G., Spinelli, N., Amodeo, A., Chaikovsky, A., Wiegner, M., Nickovic, S., Papayannis, A., Perrone, M., Rizi, V., Sauvage, L., and Stohl, A.: Volcanic dust characterization by EARLINET during Etna's eruptions in 2001-2002, Atmos. Environ., 42, 893-905, https://doi.org/10.1016/j.atmosenv.2007.10.020, 2008.

Wiegner, M., Groß, S., Freudenthaler, V., Schnell, F., and Gasteiger, J.: The May/June 2008 Saharan dust event over Munich: Intensive aerosol parameters from lidar measurements, J. Geophys. Res., 116, D23123, https://doi.org/10.1029/2011JD016619, 2011.

Wiegner, M., Gasteiger, J., Groß, S., Schnell, F., Freudenthaler, V., and Forkel, R.: Characterization of the Eyjafjallajökull ashplume: Potential of lidar remote sensing, Phys. Chem. Earth, 4546, 79-86, https://doi.org/10.1016/j.pce.2011.01.006, 2012.

Wiegner, M., Madonna, F., Binietoglou, I., Forkel, R., Gasteiger, J., Geiß, A., Pappalardo, G., Schäfer, K., and Thomas, W.: What 
is the benefit of ceilometers for aerosol remote sensing? An answer from EARLINET, Atmos. Meas. Tech., 7, 1979-1997, https://doi.org/10.5194/amt-7-1979-2014, 2014.
Wilks, S.: Multivariate statistical outliers, Sankhya: The Indian Journal of Statistics, 4, 407-426, 1963. 